HNF-2773

Revision 0

UC-2000

\title{
Strategic Plan for Infrastructure Optimization
}

DynCorp Tri-Cities Services, Inc.

Date Published

June 1998

Prepared for the U.S. Department of Energy

Fluor Daniel Hanford, Inc.

P.O. Box 1000

Richland, Washington

Hantord Management and Integration Contractor for the

U.S. Department of Energy under Contract DE-AC06-96RL13200

Approved for Public Release; Further Dissemination Unlimited 


\section{RELEASE AUTHORIZATION}

Document Number: HNF-2773, Revision 0

Document Title: $\quad$ Strategic Plan for Infrastructure Optimization

This document, reviewed in accordance with DOE Order 1430.1D, "Scientific and Technical Information Management," and DOE G 1430.1D-1, "Guide to the Management of Scientific and Technical Information," does not contain classified or sensitive unclassified information and is:

\section{APPROVED FOR PUBLIC RELEASE}
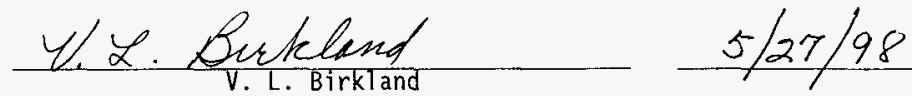

Lockheed Martin Services, Inc. Document Control/Information Clearance

Reviewed for Applied Technology, Business Sensitive, Classified, Copyrighted, Export Controlled, Patent, Personsl/Private, Proprietary. Protected CAADA. Trademark. Unclassified Controlled Nuclear Information.

LEGAL DISCLAIMER. This report was prepared as an account of work sponsored by an agency of the United States Govemment. Neither the United States Government nor any agency thereof, not any of their employees, nor any of their contractors, subcantractors or their employees. makes any warranty, express or implied, or assumes any legal liability or responsibility for the accuracy. completeness, or any third party's use or the results of such use of any information, apparatus, product, or process disclosed, or represents that its use would not infringe privately owned rights. Reference herein to any specific commercial product, process, or service by trade name, trademark, manufacturer, or otherwise, does not necessarily constitute or imply its endorsement,

recommendation, or favoring by the United States Government or any agency thereof or its contractors or subcontractors. The views and opinions of authors expressed herein do not necessarily state or reflect those of the United States Government or any agency thereof. This report has been reproduced from the beet avsilable copy. Printed in the United States of America, Available to the U.S. Department of Energy and ite contractors from the U.S. Depertment of Energy Offjce of Scientific and Tochnical information, P.O. Box 62. Oak Ridge, TN 37831: Tolephone: 423/576-8401.

Available to the public from the U.S. Department of Commerce National Techrical Information Service, 5285 Port Royal Road, Springfiald, VA 22161: Telephone: 703/487-4650. 


\section{INFORMATION CLEARANCE FORM}

\begin{tabular}{|c|c|c|}
\hline \multicolumn{2}{|c|}{ A, Information Category } & B. Documenz Numba! HNF-2773 REV.O \\
\hline 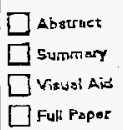 & $\begin{array}{l}\square \text { Joumal Ariele } \\
\square \text { interner } \\
\square \text { sormera } \\
\square \text { Regor }\end{array}$ & $\begin{array}{l}\text { C. TIA STRATEGIE PLAN PIR } \\
\text { I NFRASTRUCTURE OPTIMIZATION }\end{array}$ \\
\hline 口other & 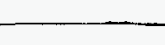 & a. In \\
\hline
\end{tabular}

艾

E. Heguirod Inform ation

E. 具

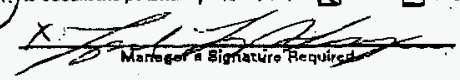

$$
\text { it Ya: }
$$

$$
\text { ADC Signative Fequirod }
$$

2. Intumal Pxwicw Ro Flired?

$\square$ No $\square$ ret clacuilfiod

counual

Proaram

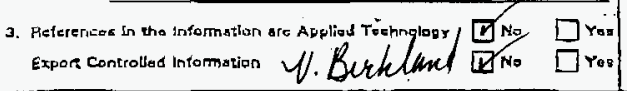

(4)

4. Dae Infomation Contain thia Fullowing: IMANDATORY

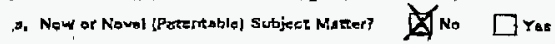

If -You". Disclozure No,:

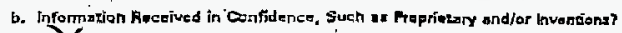

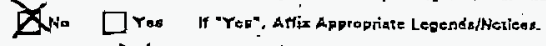

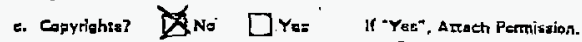

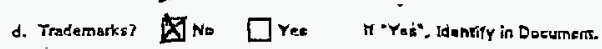

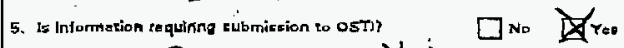

"T. UC- 900 and B\&R- YNO10100

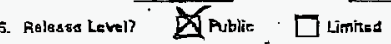

7. charga code TASK AAN85300 (MDF53)

\section{F. Comploto for a Jaumal Ariels}

1. Thle of Joumb:

G. Completo for a Prasentation

1. Trito for Coníterenco or Meathy

2 Group Sponsaring

3. Dive of Comparentes

5. Will informotien. but Publithed in Froegedinat? $\square$ No $\square$ Yoe

4. Ery/state

H. Author/Requestor.

炎

Clint Denle,

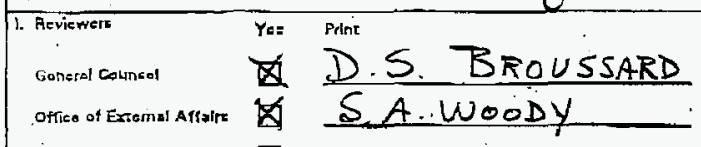

ONEFRL

Othar.

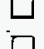

Other
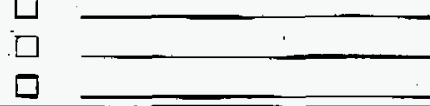

6. Wal Material be Handod Out? $\square$ Na $\square$ Yes Alsponsible Monager

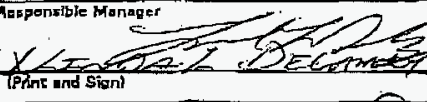
Phne and sieni
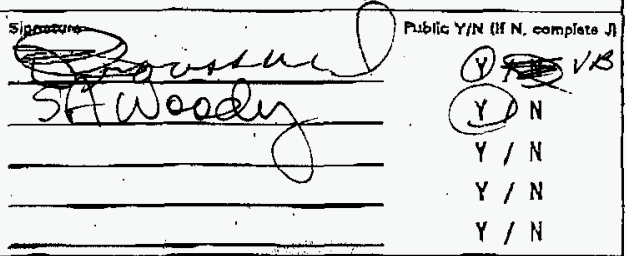

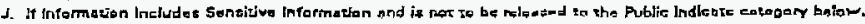

$\square$ Apptrad Therenology $\square$ Protejtad CRADA

$\square$ farmonalfrivato $\square$ Expart tontrollod

Q Propdatay $\square$ Pracurtment-Sensizive

$\square$ Business-Sonsintive $\square$ Patentable

$\square$ Produclainal $\square$ Other (6pogift)

$\square$ UCNI

K. If Additional Commentu. Ple aje Atroch Soparals She et 


\title{
Strategic Plan for \\ Infrastructure Optimization
}

\section{TABLE OF CONTENTS}

\author{
TRANSMITTAL LETTER
}

TABLE OF CONTENTS

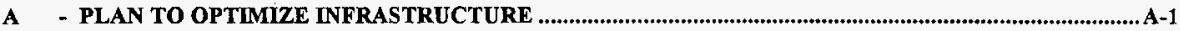

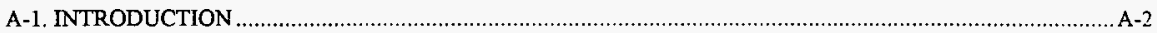

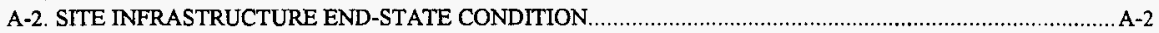

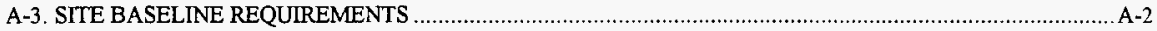

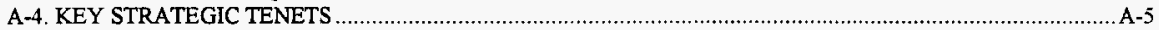

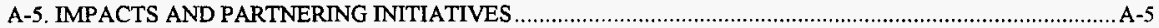

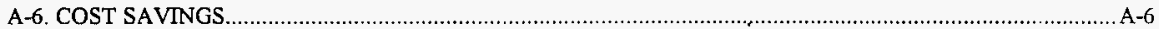

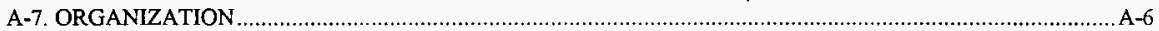

A-8. SUMMARY

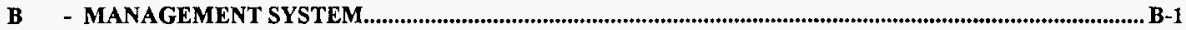

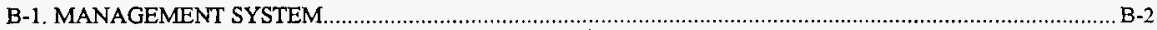

B-2. SITE INFRASTRUCTURE BUSINESS PROCESS FUNCTION MODEL ……....................................... B-2

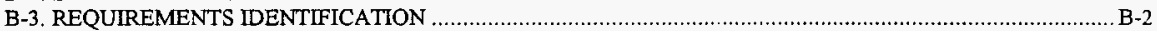

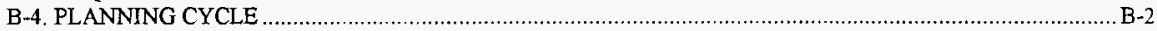

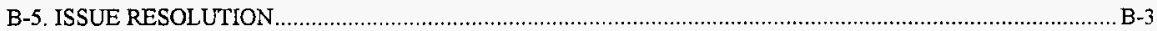

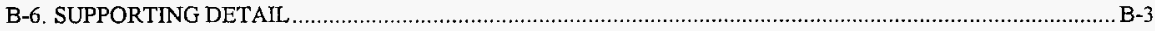

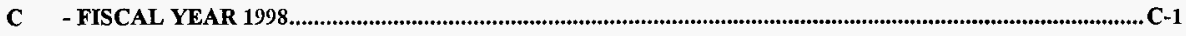

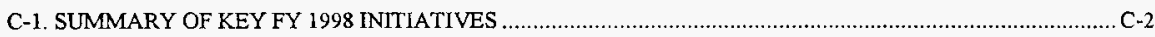

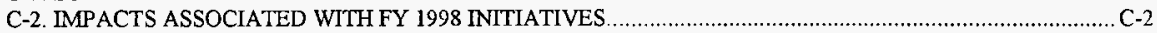

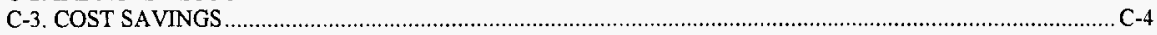

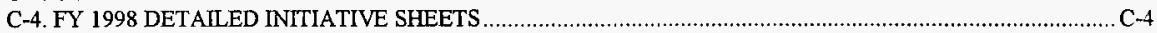

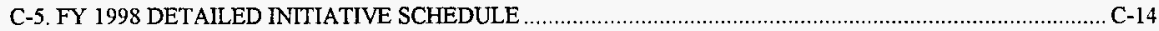

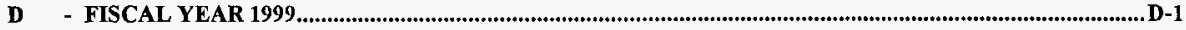

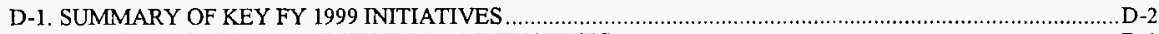

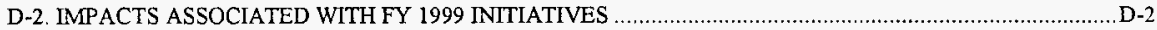

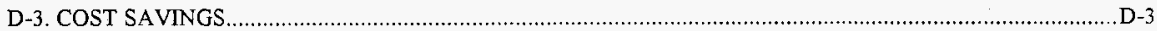

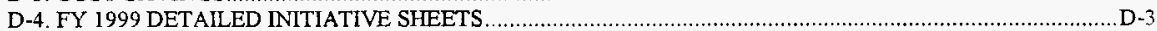

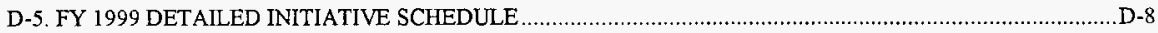

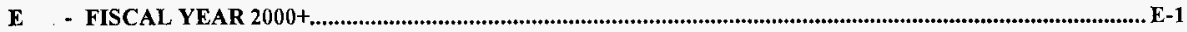

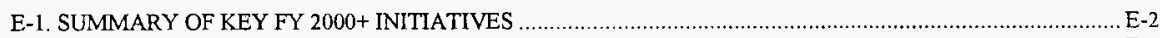

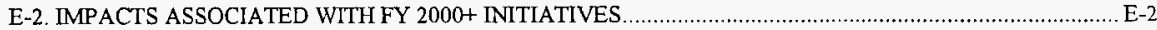

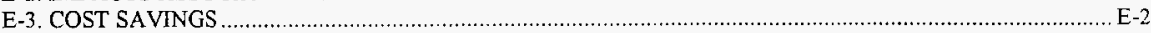

E-4. FY 2000+ DETAIILED INITIATIVE SHEETS

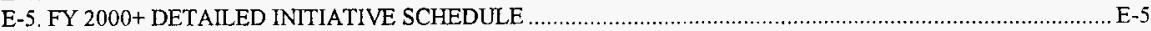

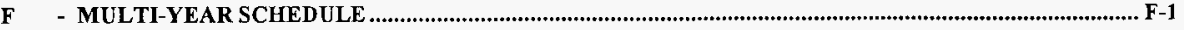

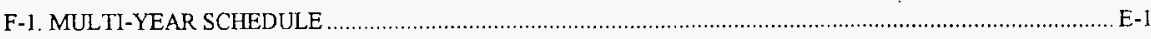

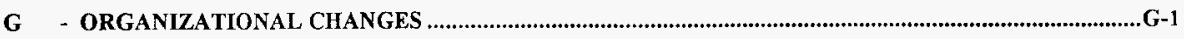

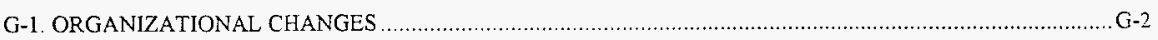




\section{Strategic Plan for \\ Infrastructure Optimization}

\section{A - PLAN TO OPTIMIZE INFRASTRUCTURE}




\section{Strategic Plan for \\ Infrastructure Optimization}

\section{A-1. INTRODUCTION}

This document represents Fluor Daniel Hanford's and DynCorp Tri-Cities' Strategic Plan for Fiscal Years 19982002 - the road map that will guide us into the next century and our sixth year of providing safe and cost effective infrastructure services and support to the Department of Energy (DOE) and the Hanford Site. The Plan responds directly to the issues raised in the FDH/DOE Critical Self Assessment, specifically: 1) "... a strategy in place to give DOE the management (systems) and physical infrastructure for the future;" 2) "...dealing with the barriers that exist to making change;" and 3) "... a plan to right-size the infrastructure and services, and reduce the cost of providing services..." The Plan incorporates initiatives from several studies conducted in Fiscal Year (FY) 1997 to include; the Systems Functional Analysis, 200 Area Water Commercial Practices Plan, \$ million Originated Cost Budget Achievement Plan, the 1100 Area Vacate Plan, the Railroad Shutdown Plan, as well as recommendations from the recently completed Review of Hanford Electrical Utility by $D$. Hittle and Associates. These and other initiatives identified over the next five years will result in significant improvements in efficiency, allowing a greater portion of the infrastructure budget to be applied to Site cleanup. The Plan outlines a planning and management process that defines infrastructure services and structure by linking site technical baseline data and customer requirements to work scope and resources. The Plan also provides a vision of where Site infrastructure is going and specific initiatives to get there.

\section{A-2. SITE INFRASTRUCTURE END-STATE CONDITION}

Remediation of the Hanford Site should complete within the next 50 years. The Hanford Site footprint will be reduced to a minimum. Property that has been cleaned and/or declared surplus to the needs of the DOE will be transferred to others, causing the Department's administrative control zone to shrink significantly. Only that area of land necessary for use as a controlled waste disposal area in perpetuity will remain in Federal government control. At that time Site activity is expected to be limited to surveillance of solid waste burial grounds in the 200 Areas, and perhaps some continuing groundwater pump-and-treat and monitoring activities. Facilities and systems shutdown, decontamination and decommissioning (D\&D), and cleanup continue from now until then. Reducing the infrastructure footprint will be possible in the 100 Areas as environmental restoration activities in those areas complete over the next 10 to 15 years. During the same period increases in electrical power and water requirements will be generated by construction and start-up of TWRS Phase II vitrification in the 200 Area. Additionally, significant transportation requirements will also be generated with the advent of burial ground closure activities in the 200 West Area. The 300 Area waste sites, materials, and facilities will be remediated to allow industrial and economic transition. Requirements for related infrastructure requirements will transition accordingly

Long before DOE's Hanford Site footprint is reduced to its final minimal configuration, and within the next five years, the desired end-state condition will have been reached: Only those services necessary to support the site mission are being provided, and those services are being provided in a cost-effective manner. This means that legacy, non-essential services, excess capacity and redundant service and support will have been eliminated, and services and support being provided have been truly optimized.

\section{A-3. SITE BASELINE REQUIREMENTS}

Fundamental to the development of a strategy for optimizing infrastructure is the necessity to understand requirements driven by the Site mission. Accordingly, the plan is based on an understanding of those requirements as obtained from the systems engineering technical baseline and other Site sources. DynCorp will become an active participant in the utilization of these systems and sources, and significantly expand the acquisition and use of the data from these systems to develop proposed changes to the level and scope of infrastructure services. These systems and sources will also be used to determine and verify impacts to the projects as a result of proposed infrastructure changes in order to implement intelligent support and service adjustments commensurate with mission requirements.

An evaluation of systems enginecring data in the current technical baselinc indicates plans for the shutdown/closure and construction/startup of several major facilities during the immediate five-year planning period FY 1998-2002. Major

Portions of this page may have blanks or missing information due to 


\section{Strategic Plan for \\ Infrastructure Optimization}

Site milestone activities which will affect infrastructure services have also been identified in the following FY planning periods: 2003-2007; 2008-2017; 2018-2032; and 2033-2048. Activities which are expected to influence the requirements for infrastructure support in the immediate five-year planning period are addressed in the paragraphs that follow. Initiatives to align with these trends and activities are located in FY 1998-2000 Plans in Tabs B, C and D.

Five-year Planning Period FY 1998-2002

100K Area - Construction activities will complete by FY 2001, removal of fuel will begin, and sludge removal may begin. Deactivation of the basins is not expected to begin in this five-year planning period. Until deactivation begins in FY 2003, water and electric services will remain at essentially current levels. Fuel and sludge removal will require additional transportation services, and road maintenance on Route 1 and Route 4 will increase due to heavy truck traffic.

$100 N$ Area - N Reactor deactivation will complete during this five year planning period. Electric and water services and maintenance of the 100 Area lagoon will be gradually reduced. Road maintenance, and facility management and maintenance will decrease. Actions required to recover government personal property will increase.

Other 100 Areas - Remediation will continue, but is not expected to complete during the planning period. Infrastructure services such as utilities, road maintenance, and recovery of government personal property will continue at essentially current levels.

200 East Area - PUREX was shut down in 1997. The 284E Powerhouse will be shut down and B Plant will be deactivated in 1998. In 1999 the only facilities still operating will be tank farms/evaporator, the Treated Effluent Disposal Facility, the Canister Storage Facility, offices, and infrastructure support facilities (shops, warehousing, crane and rigging, water plant, package boilers, etc.). Offices and support facilities will continue to be shut down as the area population and demand for service decreases. Facility management and maintenance, janitorial, loaned labor, fabrication, fleet equipment maintenance, transportation, road maintenance and utilities services will be aligned with requirements. TWRS Phase I Privatization construction will begin in FY 1999 creating increased demands for electricity and water. Road traffic volumes will increase during the construction period, requiring additional road maintenance.

200 West Area - The Transuranic Storage and Assay Facility (TRUSAF) will shut down, PFP stabilization will progress, and $291 Z$ deactivation will continue. Tank retrieval system(s) will be installed and the Environmental Restoration Storage Facility (ERDF) expansion is scheduled to be completed. An increase in heavy truck traffic during ERDF construction is expected, resulting in additional road maintenance requirements. ERDF warehousing requirements will decrease. Some decrease in utilities and services will result from facility shutdown and deactivation.

300 Area - Over $100(60 \%)$ of the 300 Area facilities (approximately 98,000 square feet) (both contaminated and uncontaminated) will be deactivated/decontaminated and decommissioned to include the 384 Powerhouse. Demand for electrical and water utilities will decrease by $50 \%$. Facility management and maintenance and custodial support will decrease significantly, as will road maintenance due to reduced traffic.

400 Area - The FFTF mission is still in question. The current baseline indicates transition of the facility from standby to ready-for-D\&D during the planning period. Accordingly, demand for services would decrease. An alternate scenario would be for FFTF to be restarted after assignment of a new mission. In this case services would escalate to operating facility levels. Current service levels will remain constant until a final decision is made.

1100 Area - Rail services will be transferred/shutdown by September 30, 1998. Transportation and maintenance functions will consolidate in the 200 Area. Demand for utilities and services, facility management and maintenance, and custodial services will decrease accordingly. 


\section{Strategic Plan for \\ Infrastructure Optimization}

During the years FY 2003-2007

- Remediation in the $100-B, D$, and $H$ Areas will be completed

- The $100 \mathrm{~K}$ basins will be deactivated

- The ERDF will be expanded a second time

- TWRS Phase II will begin construction

- $\mathrm{D} \& \mathrm{D}$ of 41 facilities in the 300 Area will begin

During the years FY 2008-2017

- Remediation in the $100-\mathrm{N}, \mathrm{F}$, and $\mathrm{K}$ areas will be completed

- TWRS Phase I Privatization will complete operations

- TWRS Phase II construction will complete and operations begin

- The 242A Evaporator will complete operations

- Tank farm closures will begin

- Burial ground closures will begin with significant transportation requirements

- D\&D of 41 facilities in the 300 Area will be completed

During the years FY 2018-2032

- All remediation in the 100 Areas will be completed

- TWRS Phase I D\&D will be completed

- TWRS Phase II operations will end and D\&D begin

- D\&D of 126 facilities in the South 600 Area will begin

- Tank farm and burial ground closure will continue

During the years FY 2033-2048

- 200 Area Laboratory, Solid Waste, and Liquid Effluent operations will cease

- FFTF Operations will cease

- Remediation in the 200,300 , and 400 Areas will be completed

As plans and initiatives are developed to align infrastructure with changing project and site requirements they will be coded into the Site Systems Engineering Technical Baseline (STB), Performance Measurement Control System (PMCS), the TWRS Master Summary Schedule, the Site Master Baseline Schedule, and the Cost Account Schedule. The interactive capabilities of these baseline databases, will provide visibility to Site planners of infrastructure considerations related specifically to them, and develop the mechanism for closely coupling infrastructure planning to project requirements. This interaction within these relational databases will provide the opportunity to develop additional cost-effective and timely infrastructure initiatives and actions aligned with Site and project planning. 


\section{Strategic Plan for \\ Infrastructure Optimization}

\section{A-4. KEY STRATEGIC TENETS}

The following tenets will guide efforts to achieve the desired end-state. These tenets also define actions that must be accomplished in order to provide services consistent with commercial practices and fully integrate infrastructure services with Site and Project mission requirements:

Integrate infrastructure services with site and project mission requirements

- Align services to mission requirements by:

- Identifying applicable site and project requirements

- Determining that services provided are only those required to meet mission requirements

- Optimizing the organization and levels of support commensurate with the services required and provided.

- Challenge requirements by:

- Identifying and verifying basis of the requirement

- Developing alternative, cost effective methods, to provide services

- Eliminating services no longer required to meet site and project mission

Provide services consistent with commercial practices

- Streamline work processes and structures by:

- Streamlining the management structure

- Implementing technical process improvements

- Creating a flexible workforce

- Eliminating productivity barriers

- Reducing inventory, space, and equipment to manage and maintain

- Eliminate unnecessary practices/requirements by:

- Identifying the basis for the practice/requirement

- Satisfying only those requirements necessary for safe, compliant, efficient, and cost effective management of site infrastructure

- Instituting commercial billing and practices by:

- Baselining/benchmarking costs/practices

- Changing the current method of cost liquidation

- Establish competitive environment by:

- Establishing a services acquisition approach

- Privatizing and or subcontracting all available services

- Performing cost/benefit analysis

\section{A-5. IMPACTS AND PARTNERING INITIATIVES}

The initiatives that are proposed in this five-year plan will have both positive and negative impacts to the site and projects. These impacts are listed by fiscal year at Tabs C, D, and E. Several partnering initiatives will be required to fully implement the initiatives contained in the five-year plan. They are summarized below:

\section{HAMTC Partnering Initiatives}

1. Reorganization/Re-engineering as a result of combining functions and organizations

2. Privatizing and sub-contracting to create competitive environment and support economic transition

3. Support job classification work scope reviews 


\section{Strategic Plan for \\ Infrastructure Optimization}

\section{FDH/RL Partnering Initiatives}

1. Centralized management of all office space including programmatic by DynCorp

2. Added project responsibility for GPF management and maintenance

3. Potential changes to fee and contract structure

4. Elimination of overly-restrictive, non-commercial requirements

5. Successful accomplishment of privatization and outsourcing efforts

6. Improvement/change to billing practices and rates

7. Development of a multi-year work planning process for infrastructure

8. Full integration of infrastructure - improving system/process to identify site requirements

9. FDH-Economic Transition to facilitate privatization and outsourcing

10. Funding for energy conservation projects in FY 1998-2002

\section{Projects and Others Partnering Initiatives}

1. Elimination of level and scope of infrastructure services provided to projects and customers

2. Elimination of railroad, requiring alternative source of transportation

3. Establish mutual aid agreements with local electrical utilities

4. Agreement with DESH to facilitate DynCorp assuming control of $100 \mathrm{~K}$ water system

5. PHMC and other site contractors regarding the elimination of GSA sedans and use of Privately Owned Vehicles (POV)

6. Commercial sector - expansion of business base in those areas selected for privatization

\section{A-6. COST SAVINGS}

DynCorp is proposing 48 initiatives in FY 1998 in addition to those in the FY 1998 Annual Work Plan that will result in increased efficiencies, progress in optimization efforts, and a $\$ 7.6$ million reduction in originated costs. These initiatives will also result in more than $\$ 39$ million in total site savings. FY 1999 and beyond initiatives provide a vision of site infrastructure direction and future performance objectives resulting in an additional \$4.3 million reduction in originated cost and an estimated $\$ 59.8$ million in total site savings during the FY 1998-2002 period.

\section{Table A-6.1. Cost Savings Summary}

\begin{tabular}{|l|c|c|}
\hline \multicolumn{1}{|c|}{ FY Initiative } & Indirect Budget Reductions & Cost Savings FY 1998-2002 \\
\hline FY 1998 Total & 7588.0 & 39014.0 \\
\hline FY 1999 Total & 1714.0 & 12375.0 \\
\hline FY 2000+ Total & 2600.0 & 8355.0 \\
\hline & 11902.0 & 59744.0 \\
\hline
\end{tabular}

* Savings in FY 1998 through FY 2002 include originated and non-originated cost savings escalated at $3.5 \%$ annually.

\section{A-7. ORGANIZATION}

DELETED - Business Sensitive and Company Proprietary 


\section{Strategic Plan for \\ Infrastructure Optimization}

\section{A-8. SUMMARY}

This five-year plan serves as a high-level document to guide infrastructure direction and resource allocation for the five-year period. It also defines performance objectives that are outcome, vice output-oriented. The plan implements a management system that links site mission changes and requirements to budget planning and work plan development for each fiscal year. Successful implementation will result in:

- Reduced Site infrastructure footprint

- Site energy consumption significantly reduced

- Energy efficient, automated water systems

- Streamlined, commercially competitive electrical utilities organization

- Flexible, just-in-time workforce

- Reduction in Company and Department overhead

- Significantly less space and equipment to manage and maintain

- Unnecessary and overly restrictive requirements eliminated to be more in line with commercial practices

- Privatization and/or subcontracting of all available services

- A restructured contract that enables DynCorp to undertake commercial work

- DynCorp restructured and right-sized to support a new way of doing business 


\section{Strategic Plan for \\ Infrastructure Optimization}

\section{B - MANAGEMENT SYSTEM}




\section{Strategic Plan for \\ Infrastructure Optimization}

\section{B-1. MANAGEMENT SYSTEM}

Determining and undertaking effective courses of action responsive to Site infrastructure requirements and implementation of commercial practices requires a management system which identifies optimization objectives and initiatives and translates them into approved and budgeted workscope.

DynCorp employs a system that includes processes for the identification of infrastructure requirements, planning and decision making necessary to determine resources required to support identified requirements, and annual planning which translates supported requirements into annual work plans. The basic foundation of this system is the Site Infrastructure Business Process Function Model.

\section{B-2. SITE INFRASTRUCTURE BUSINESS PROCESS FUNCTION MODEL}

The business model, depicted in Figure B-2.1, provides basic guidance for linking supported work scope to the Site Mission, for eliminating unnecessary services, and for streamlining work processes and organizational structure. The model is built on two basic tenets: integration of infrastructure services with site and project mission requirements, and providing services consistent with commercial practices. The model demands continuous effort to identify infrastructure requirements, guides decision making related to how identified requirements are to be addressed, and is linked to an annual cycle for the development of approved and budgeted work plans.

\section{B-3. REQUIREMENTS IDENTIFICATION}

DynCorp will be an active participant in the utilization of Site systems such as the Site Systems Engineering Technical Baseline (STB), the Performance Measurement Control System (PMCS), and the Site Master Baseline Schedule (SMBS), and will utilize the data from these systems for planning purposes. DynCorp will also code infrastructure planning into these systems to provide visibility to Site planners of infrastructure considerations related specifically to them, and to develop the mechanism for closely coupling infrastructure planning to project requirements.

\section{B-4. PLANNING CYCLE}

The infrastructure annual work planning and budget cycle starts with the determination of requirements related to accomplishment of the Site mission, applies the guidance of the Business Process Function Model to the development of initiatives required to satisfy identified requirements, and concludes with an approved annual work plan. At the same time, a master annual schedule is developed and outyear requirements and initiatives are considered for the entire span of the rolling five-year planning cycle.

The planning process, depicted in Figure B-4.1, starts in October after the execution year annual work plans have been approved. The Infrastructure Strategic Plan is updated to change initiatives into approved actions. At the same time, DynCorp will code approved infrastructure initiatives and milestones into the STB and the PMCS. Approved plans, initiatives, and milestones reflected in the programmatic and project annual work plans are expected to be coded into the same systems. The relational capabilities of STB, PMCS, and SMBS are then expected to provide a current insight into any changes that must be made in infrastructure planning based upon changed and approved programmatic/project requirements.

Subsequent to updating the strategic plan and the STB, PMCS, and SMBS databases, and in the month of November, Site and Customer infrastructure requirements necessary to support the Site mission are identified. This is done for the entire five year planning period, but with emphasis on the following fiscal year.

The STB, PMCS, and SMBS indicate principally milestones, and only infer level of service effort necessary to support infrastructure requirements between changes evidenced by those milestones. Accordingly, infrastucture functional 


\section{Strategic Plan for Infrastructure Optimization}

experts will pay particular attention to the optimization of static state service levels required between significant milestone changes. This is, perhaps, the greatest challenge in determining an optimized infrastructure.

After infrastructure requirements are determined, prioritization of infrastructure effort is done beginning in November and into the month of January. Optimized static state service levels and changes in effort to respond to changes in Site requirements are resource loaded and an unconstrained draft budget submittal is developed

Fluor Daniel Hanford issues Site planning rates in January. Using these rates the draft budget submittal is costed, and a prioritized, but unconstrained, requirements-driven, budget request prepared. This budget request will be provided to Fluor Daniel Hanford in February, with a response expected in March.

Based upon the Fluor Daniel Hanford response to the unconstrained budget request, a draft annual work plan is developed and submitted to Fluor Daniel Hanford in May. Issues are resolved during June and the final annual work plan is submitted to Fluor Daniel Hanford in June. DOE-RI approval is expected by the end of September.

Upon approval of the annual work plan the cycle starts again.

\section{B-5. ISSUE RESOLUTION}

Partnering issues and barriers to implementation of proposed initiatives are identified throughout the development and modeling validation process. Resolutions are initiative specific, however, the general ground rules and approach are as follows;

1. Union partnering issues such as the work scope revisions or jurisdictional issues will be negotiated on an individual basis with emphasis on "Win-Win" innovative solutions.

2. Project integration and increased planning emphasis will continue to be addressed. Initiatives will be strengthened or revised based upon revisions and further clarification of the Site Technical Baseline.

3. Reduction in services provided to the projects, as a result of a changing Site Mission, will be reviewed and impacts clarified. Alignment with customer needs and reduced costs for infrastructure support will be ongoing and will be addressed and resolved based upon mutual agreements between FDH and DOE-RL.

4. Accounting practices/billing, rates, etc. issues will be addressed in order to achieve mutually acceptable agreements that promote cost competitiveness.

5. Evaluation of contract and non-commercial requirements will be addressed with the appropriate FDH and DOE-RL representatives for waivers and/or interpretation of minimun compliance requirements.

6. Funding issues such as investment requirements for energy conservation and automation projects in support of cost savings benefits will be option oriented and submitted well enough in advance to influence budget development.

\section{B-6. SUPPORTING DETAIL}

Specific initiatives to support the infrastructure end-state condition have been identified for the next five-years These initiatives have been organized by Fiscal Year and are included in Tabs C, D and E. The initiatives will serve as the basis for further work scope planning and budget determination. Each section includes a description of the tenets and areas of focus for the current year, an explanation of each initiative, and a supporting implementation schedule. 
FigUre B-2.1. SITE INFRASTRUCTURE BLSINESS PROCESS FUNCTION MODEL

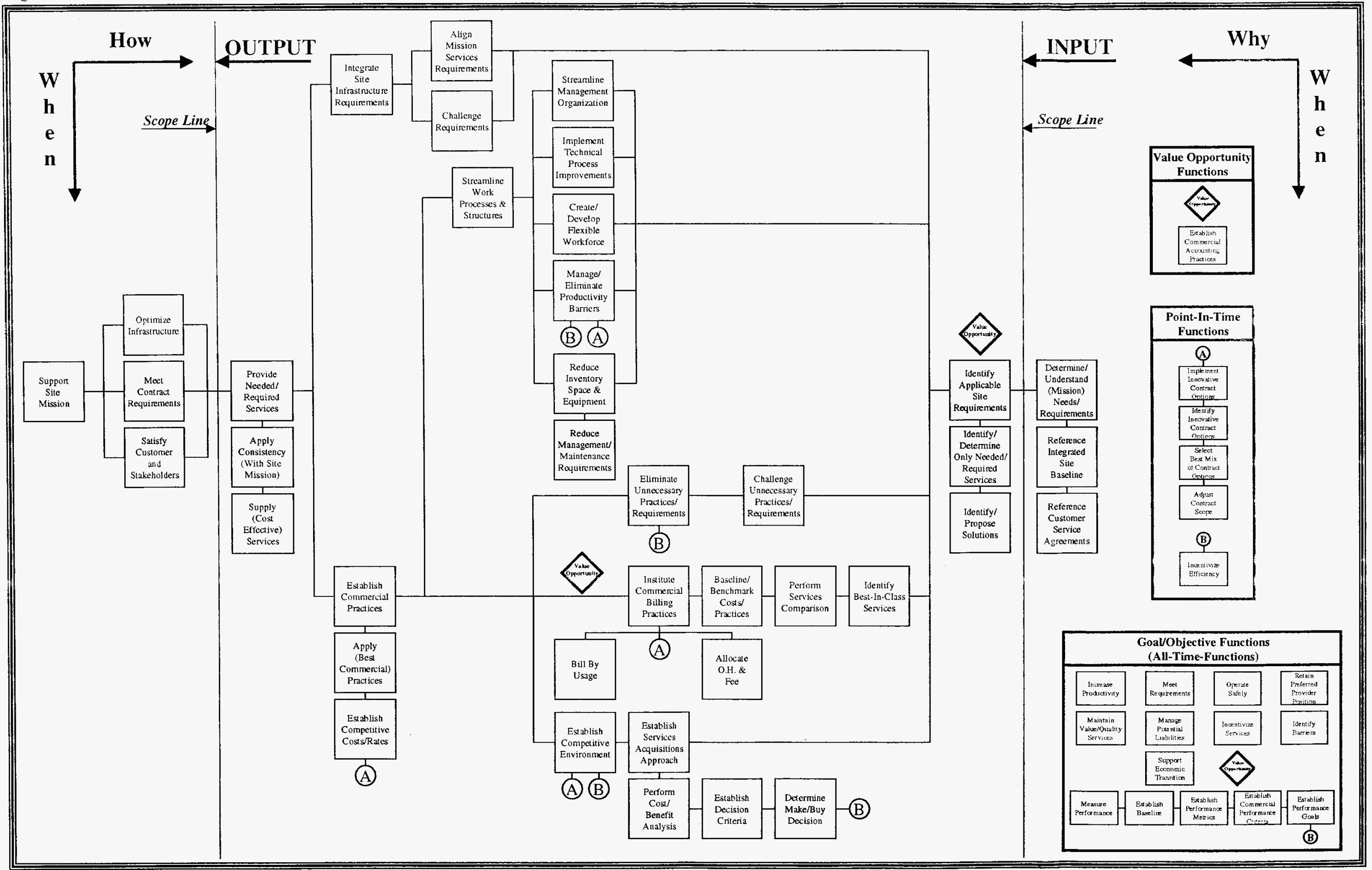




\section{Infrastructure Annual Work Planning And Budget Cycle}

Figure B-4.1 Infrastructure Annual Work Planning And Budget Cycle

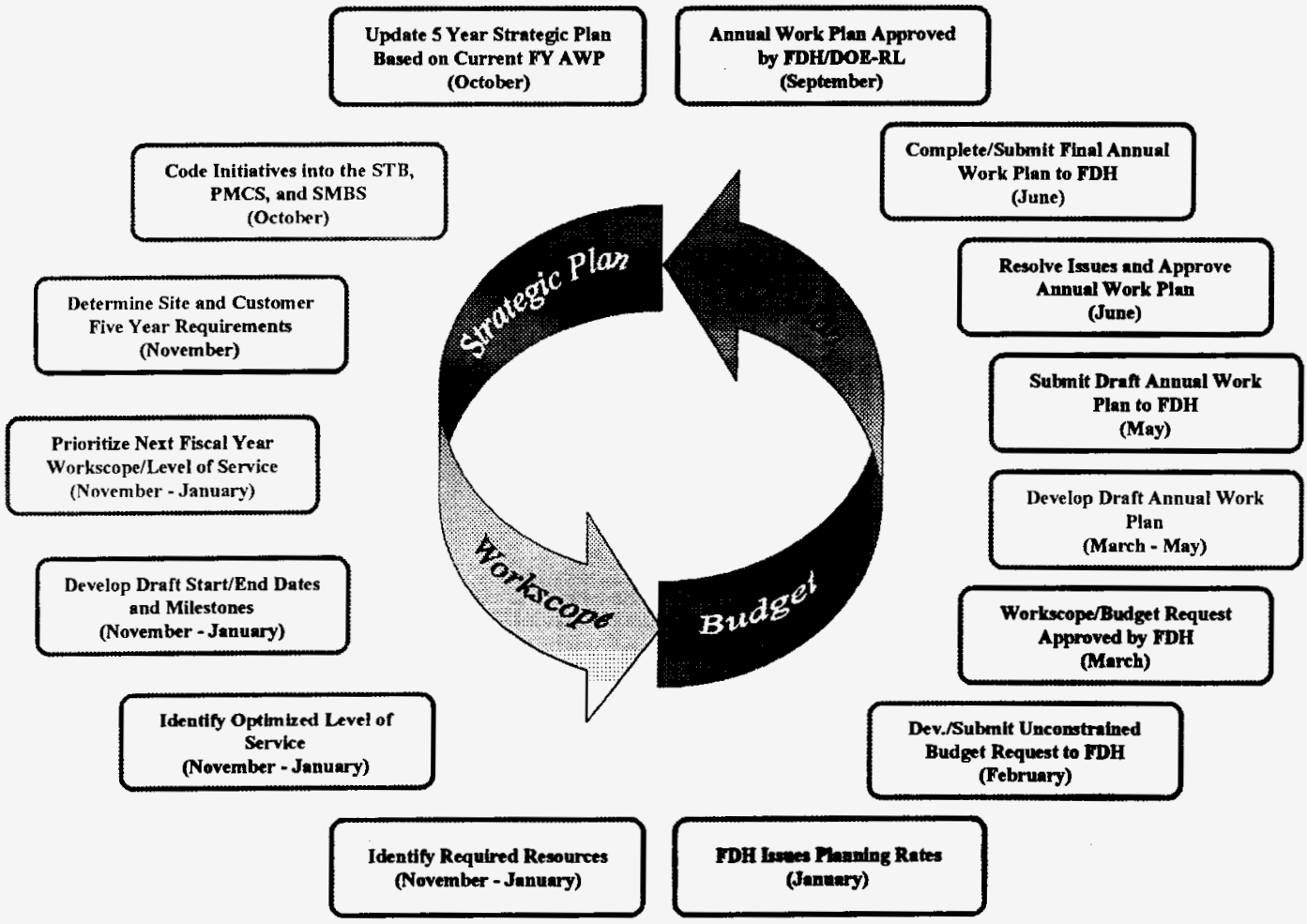




\title{
Strategic Plan for \\ Infrastructure Optimization
}

\author{
C - FISCAL YEAR 1998
}




\section{Strategic Plan for \\ Infrastructure Optimization}

\section{C-1. SUMMARY OF KEY FY 1998 INITIATIVES}

\section{Initiatives to Provide Services Consistent with Commercial Practices}

1. Reduce overhead - streamline management structure by reducing Company and Department overhead, improve supervisor-to-craft ratios, and combine similar functions/organizations (e.g. maintenance, engineering, and facility management).

2. Privatize/transition services/support into commercial sector (i.e., transitioning Site Fabrication Services, Calibration Lab, maintenance of GSA leased equipment, management of fleet spares, and selected ESH\&Q functions.)

3. Create a flexible, leveraged workforce by acquiring just-in-time services.

4. Reduce/eliminate unnecessary overly restrictive requirements to be more in line with commercial practices.

5. Reduce Site energy consumption by replacing and/or removing energy inefficient pumps and oversized transformers.

6. Eliminate under-utilized Government Furnished Equipment (GFE) by utilizing commercially available equipment to meet peak demands.

7. Eliminate GSA sedan fleet.

8.

9. Implement recommendations from $\mathrm{D}$. Hittle report to bring electrical utilities more in line with commercial practices.

10. Revise the current subcontract to enable DynCorp Tri-Cities Services, Inc. to undertake commercial work.

\section{Initiatives to Fully Integrate Infrastructure}

1. Reduce workforce in conjunction with reductions in scope.

2. Reduce space, equipment and inventory consistent with mission requirements by:

- Eliminating 703 and 2425 Stevens Center commercial leases, 50,000 square feet of mobile office space, and shutting down $2701 \mathrm{~W}$ and $2715 \mathrm{WC}$.

- Excessing $\$ 50 \mathrm{M}$ in inventory.

- Reducing GFE equipment pool by $61 \%$ (100 items) .

- Initiating vendor consigned fleet maintenance parts inventory, reducing per unit cost.

- Reducing Site footprint by eliminating oversized equipment/excess capacity in water and electrical infrastructure.

- Eliminate 82 GSA sedans.

- Vacating 1171 Facility, centralizing fleet operations in the 200 Area.

3. Reduce costs to the customer and site by insuring services being provided are only those services required to support the Site Mission.

4. Transition/shutdown the Hanford railroad.

\section{C-2. IMPACTS ASSOCIATED WITH FY 1998 INITIATIVES}

- Elimination of in water operations will result in longer response duration to emergencies and non-emergencies. Average response duration to non-emergencies will increase from 1-3 days to 5-15 days. Average response duration for emergencies will increase from 1 hour to 2-4 hours during the day shift and from 1-3 hours to 3-6 hours during all other shifts.

- Reduction of over $60 \%$ of underutilized GFE equipment will require customers to submit equipment requests two working days prior to use, versus the current same day service.

- Elimination of 82 GSA leased sedans will require use of privately owned vehicles. Individuals may claim reimbursement for mileage. 


\section{Strategic Plan for Infrastructure Optimization}

- Successful sub-contracting of the calibration laboratory may require customers to drop off and pick up instruments at a central point or ship directly to the vendor(s). It is also expected that the centralized recall system will be eliminated, requiring the customer to manage calibration requirements.

- Elimination of in the occupancy pool will require building administrators to assume added responsibility for facility management and maintenance coordination (e.g. lock and tag, cold weather protection).

- Elimination of FTEs in facility maintenance and custodial services will result in a reduction in the level and frequency of custodial service and maintenance.

- A reduction in utilities training support will result in customers being required to contract for their own utility related training (e.g. water hammer).

- Elimination of will result in customers being required to submit requests for crane and rigging services two days in advance, versus the current same day service.

- Replacement of energy inefficient water pumps and motors in the 300 Area will result in reductions in pressure fluctuations, fewer pipe failures, and overall improved system reliability.

- Removal of dual transformer configuration in the 200 East and West Areas, where facility mission no longer requires redundancy will result in an increase in outage duration.

- Realignment in Guaranteed Ride Home service will result in only on call service for holidays and weekends. Response duration will increase from 1 hour to 3-5 hours.

- An increase in workstation utilization will result in some forced moves that may result in operational inefficiencies.

- Replacement of pumps in the 300 Area will require $\$ 120 \mathrm{~K}$ in implementation costs. 


\section{Strategic Plan for Infrastructure Optimization}

\section{C-3. COST SAVINGS}

An overview of originated cost, FTE reductions, and total site savings by key initiative/functional area is reflected in Table C-3.1. During the five-year cycle, cost reductions and total site savings will be adjusted to reflect new initiatives as they are identified.

Table C-3.1. Cost Savings - (\$000)

\begin{tabular}{|c|c|c|c|c|c|c|}
\hline \multirow[b]{2}{*}{ Key Initiative/Functional Area } & \multirow{2}{*}{$\begin{array}{c}\text { FY } 1998 \text { Indirect Budget } \\
\text { Reductions }\end{array}$} & \multirow{2}{*}{$\begin{array}{l}\text { Cost Savings } \\
\text { FY 1998-2002 }\end{array}$} & \multicolumn{4}{|c|}{ FY 1998 FTE Reductions } \\
\hline & & & $\mathbf{E X}$ & SNE & BU & Total \\
\hline \multicolumn{7}{|l|}{ 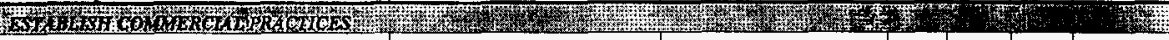 } \\
\hline Program Support & 789.0 & 1631.0 & & & & \\
\hline ESH\&Q & 359.0 & 2125.0 & & & & \\
\hline Facilities Management & 1037.0 & 5561.0 & & & & \\
\hline Site Fabrication & - & + & & & & \\
\hline Engineering Services & 102.0 & 547.0 & & & & \\
\hline Water Operations & 550.0 & 2949.0 & & & & \\
\hline Electrical Utilities & 178.0 & 2236.0 & & & & \\
\hline Fleet Operations & 557.0 & 5791.0 & & & & \\
\hline Transportation Operations & 216.0 & 1159.0 & & & & \\
\hline Materials Management & 597.0 & 2290.0 & & & & \\
\hline Hanford Standards Laboratory & - & - & & & & \\
\hline Hanford Fire Department & 60.0 & - & & & & \\
\hline Establish Commercial Practices Total & 4445.0 & $2+289.0$ & & & & \\
\hline \multicolumn{7}{|c|}{ 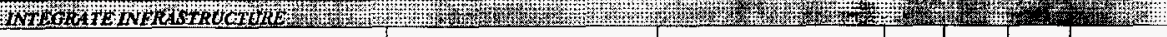 } \\
\hline Facilities Management & 1790.0 & 9599.0 & & & & \\
\hline Utilities Training. & 104.0 & 558.0 & & & & \\
\hline Site Crane \& Rigging Services & 114.0 & - & & & & \\
\hline Site Fabrication Services & 239.0 & - & & & & \\
\hline Water Operations & 89.0 & 852.0 & & & & \\
\hline Electrical Utilities & 155.0 & 1035.0 & & & & \\
\hline Fleet Operations & 204.0 & 1094.0 & & & & \\
\hline Transportation Operations & 429.0 & 1485.0 & & & & \\
\hline Materials Management & 19.0 & 102.0 & & & & \\
\hline Integrate Infrastructure Total & 3143.0 & $1+725.0$ & & & & \\
\hline FY 1998 TOTAL & 7588.0 & 39014.0 & & & & \\
\hline
\end{tabular}

* Savings in FY 1998 through FY 2002 include originated and non-originated cost savings escalated at $3.5 \%$ annually.

\section{C-4. FY 1998 DETALED INITIATIVE SHEETS}

FY 1998 initiatives are listed in Tables C-4.1. and C-4.2. 


\section{C-4.1. DETAILED INITIATIVE SHEETS}

\section{FY 1998 INITIATIVES TO ESTABLISH COMMERCIAL PRACTICES - (\$000)}

\begin{tabular}{|c|c|c|c|c|c|c|c|}
\hline \multirow[b]{2}{*}{ Initiatives } & \multirow{2}{*}{$\begin{array}{c}\text { FY } 1998 \\
\text { Indirect Budget } \\
\text { Reductions }\end{array}$} & \multirow{2}{*}{$\begin{array}{l}\text { Cost Savings } \\
\text { FY 1998-2002 }\end{array}$} & \multicolumn{4}{|c|}{ FY 1998 FTE Reductions } & \multirow[b]{2}{*}{ Comments } \\
\hline & & & $\mathbf{E}$ & SNE & BU & Total & \\
\hline
\end{tabular}

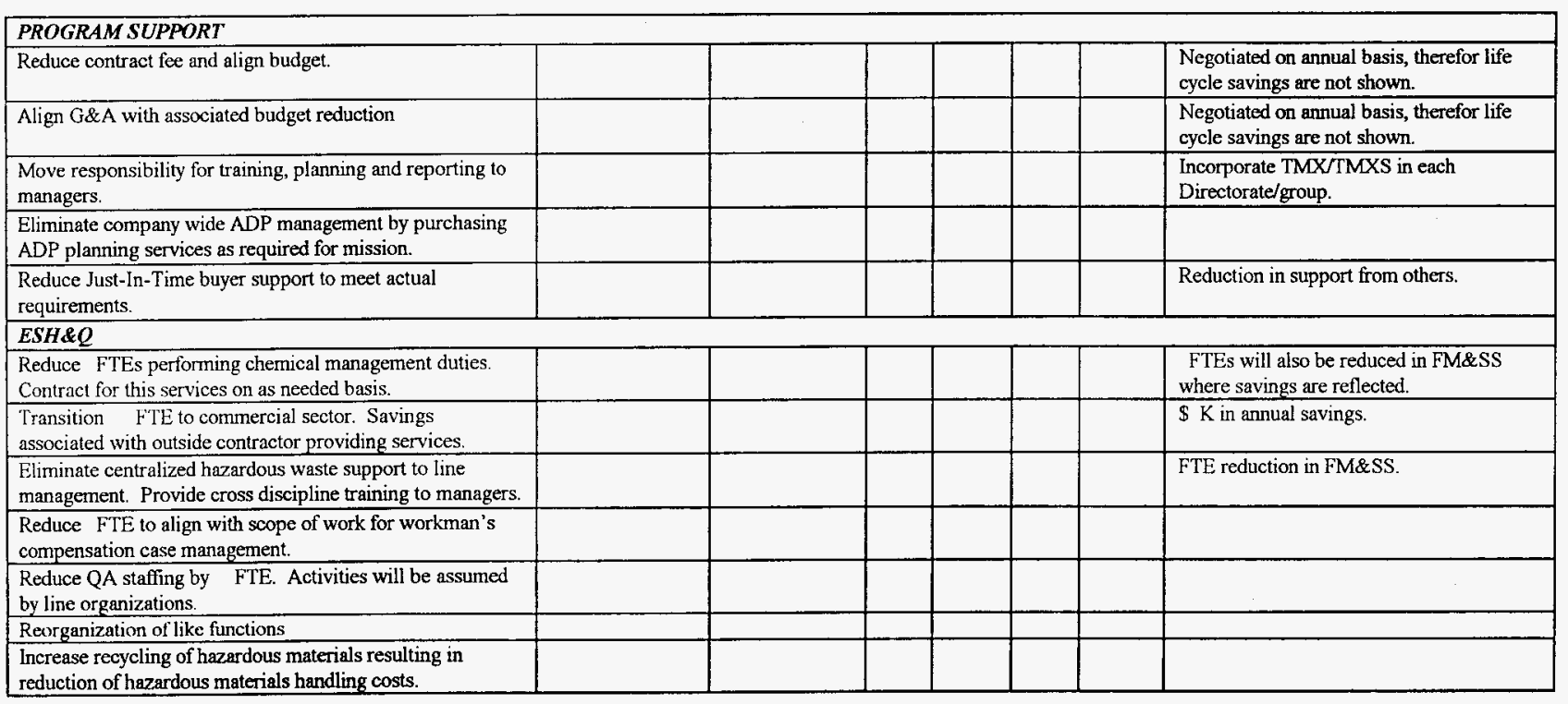




\section{C-4.1. DETAILED INITIATIVE SHEETS}

\section{FY 1998 INITIATIVES TO ESTABLISH COMMERCIAL PRACTICES - (\$000)}

\begin{tabular}{|c|c|c|c|c|c|c|c|}
\hline \multirow[b]{2}{*}{ Initiatives } & \multirow{2}{*}{$\begin{array}{c}\text { FY } 1998 \\
\text { Indirect Budget } \\
\text { Reductions } \\
\end{array}$} & \multirow{2}{*}{$\begin{array}{l}\text { Cost Savings } \\
\text { FY 1998-2002 } \\
\end{array}$} & \multicolumn{4}{|c|}{ FY 1998 FTE Reductions } & \multirow[b]{2}{*}{ Comments } \\
\hline & & & EX & SNE & BU & Total & \\
\hline
\end{tabular}

\section{FACILITY MANAGEMENT}

Target and eliminate expensive to operate \& maintain government owned facilities by eliminating $703 \& 2425$

Stevens Center commercial lease, 15 mobile offices $(49,000$

sq. $\mathrm{ft}$ ) and 2 additional buildings $2701 \mathrm{~W}$ and $2715 \mathrm{WC}$

$(7,450$ square feet).

\section{SITE FABRICATION SERVICES}

Transition SFS from the current PHMC contractor to a private company performing both $\mathrm{DOE}$ and private sector work by $9 / 30 / 98$

\section{ENGINEERING SERVICES}

Consolidate engineering functions into single department

for DYN. (Currently within ESH\&Q, Utilities, and

Facilities).

\section{WATER OPERATIONS}

Streamline operations by qualifying water operators to State licensing WTPO requirements and provide supervision

through day Superintendent

\begin{tabular}{|l|} 
\\
\hline Reduce frequency of compliance inspections. \\
\hline Eliminate employees. \\
\hline
\end{tabular}

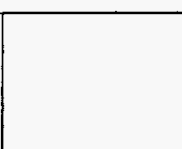

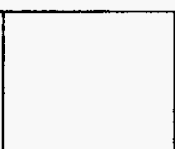

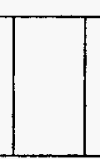

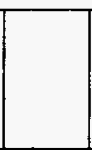

.

$\$ \mathrm{~K}$ reduction results from savings in lease costs.

\begin{tabular}{|l|l|l|}
\hline & \\
\end{tabular}

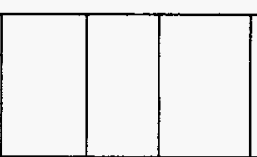

\begin{tabular}{|l|l|l|l|l|l|}
\hline & & & & & \\
\hline
\end{tabular}

e

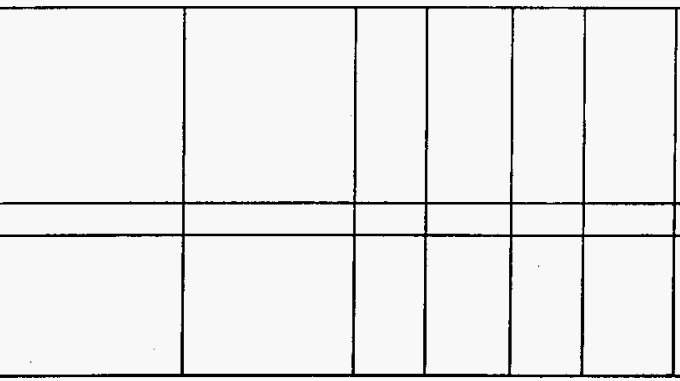

Longer response times to identify emergencies on off-shift from I hour to 3-4 hours.

Shift oversight will be provided by on-call personnel

Partner with HAMTC to accept additional responsibilities.

Reduction in support from ESH.

Increase average response time to nonemergencies from 1-3 days to 3-15 days. Emergency response times from: 1 to 2-4 hours during day shift and from 1-3 to $3-6$ hours all other shifts. 


\section{C-4.1. DETAILED INITIATIVE SHEETS}

FY 1998 INITIATIVES TO ESTABLISH COMMERCLAL PRACTICES - (\$000)

\begin{tabular}{|c|c|c|c|c|c|c|c|}
\hline \multirow[b]{2}{*}{ Initiatives } & \multirow{2}{*}{$\begin{array}{c}\text { FY } 1998 \\
\text { Indirect Budget } \\
\text { Reductions }\end{array}$} & \multirow{2}{*}{$\begin{array}{l}\text { Cost Savings } \\
\text { FY 1998-2002 }\end{array}$} & \multicolumn{4}{|c|}{ FY 1998 FTE Reductions } & \multirow[b]{2}{*}{ Comments } \\
\hline & & & EX & SNE & BU & Total & \\
\hline
\end{tabular}

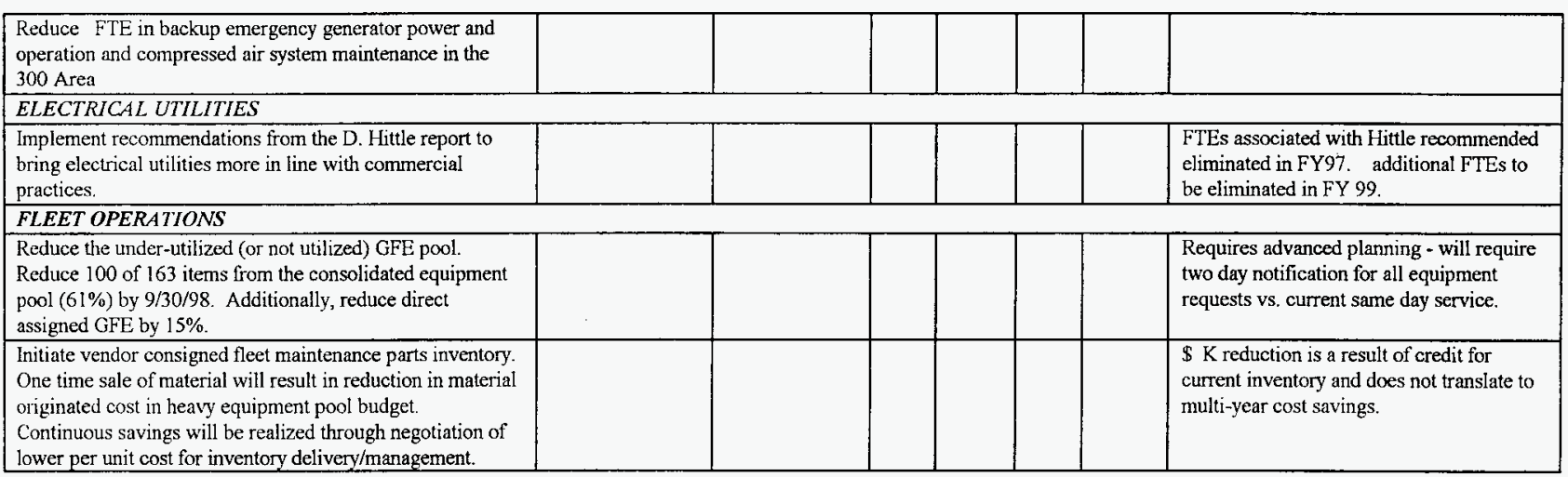




\section{C-4.1. DETAILED INITIATIVE SHEETS}

FY 1998 INITIATIVES TO ESTABLISH COMMERCIAL PRACTICES - (\$000)

\begin{tabular}{|c|c|c|c|c|c|c|c|}
\hline \multirow[b]{2}{*}{ Initiatives } & \multirow{2}{*}{$\begin{array}{c}\text { FY } 1998 \\
\text { Indirect Budget } \\
\text { Reductions }\end{array}$} & \multirow{2}{*}{$\begin{array}{l}\text { Cost Savings } \\
\text { FY 1998-2002 }\end{array}$} & \multicolumn{4}{|c|}{ FY 1998 FTE Reductions } & \multirow[b]{2}{*}{ Comments } \\
\hline & & & EX & SNE & BU & Total & \\
\hline
\end{tabular}

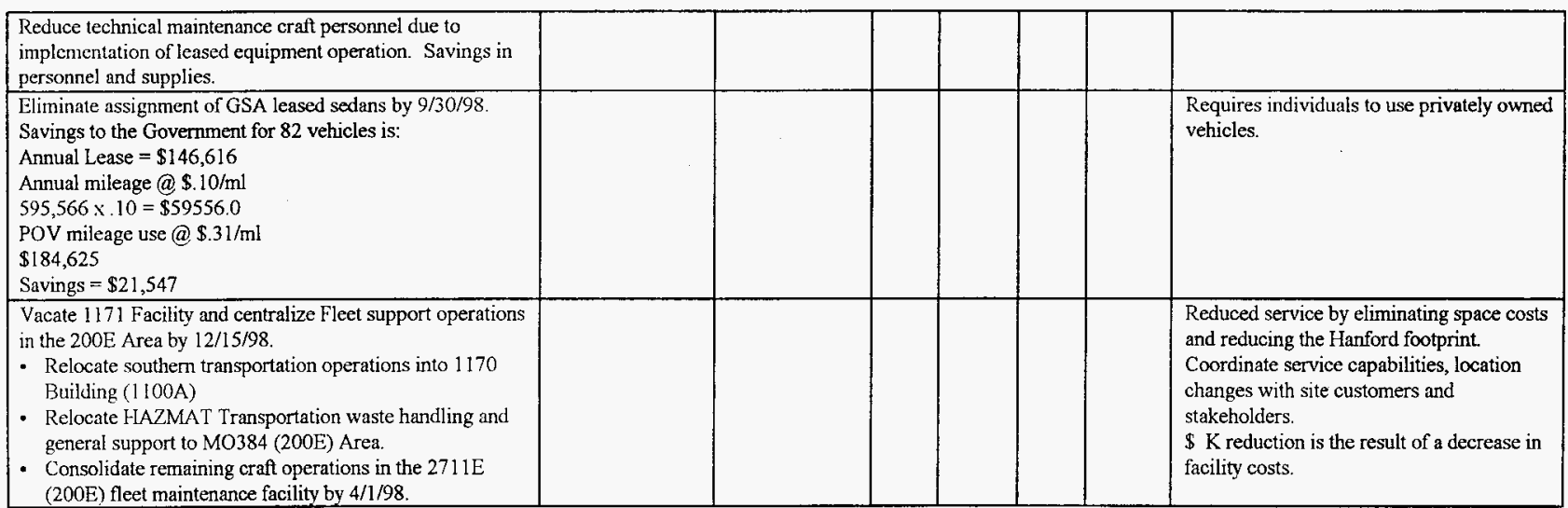




\section{C-4.1. DETAILED INITIATIVE SHEETS}

\section{FY 1998 INITIATIVES TO ESTABLISH COMMERCIAL PRACTICES - (\$000)}

\begin{tabular}{|c|c|c|c|c|c|c|c|}
\hline \multirow[b]{2}{*}{ Initiatives } & \multirow{2}{*}{\begin{tabular}{|c|} 
FY 1998 \\
$\begin{array}{c}\text { Indirect Budget } \\
\text { Reductions }\end{array}$
\end{tabular}} & \multirow{2}{*}{$\begin{array}{l}\text { Cost Savings } \\
\text { FY 1998-2002 }\end{array}$} & \multicolumn{4}{|c|}{ FY 1998 FTE Reductions } & \multirow[b]{2}{*}{ Comments } \\
\hline & & & $\mathbf{E X}$ & SNE & BU & Total & \\
\hline
\end{tabular}

\section{TRANSPORTATIONOPERATIONS}

Dissolve Waste Handling as separate organization; align staff with like functions in Consolidated Transportation Services and Road Maintenance; maximize utilization of drivers in each group; transfer sampling and monitoring functions related to Solid Waste Landfill to environmental programs supporting landlord shutdown facility operations Combine stores delivery functions in materials management with Special Delivery services; maximize utilization of resources of each group and optimize back hauls.

Consolidate outer area taxi driver classification resulting in better utilization of personnel. Eliminate multiple classification and improve productivity.

\section{MATERIAL MANAGEMENT}

Reduce inventory miscellaneous adjustment account to meet

current/future needs.

Reduce procurement quality services to realign with

commercial practices.

Combine like functions \& tasks across Materials

Management's individual departments to obtain greater

efficiencies in staff utilization. Reorganize to four

departments from five

\section{HANFORD STANDARDS LABORATORY}

Provide commercial alternative for the calibration of all or

large portions of Messuring and Testing Equipment.

\begin{tabular}{|l|l|l|l|l|l|l|}
\hline & & & & & & \\
& & & & & & \\
& & & & & & \\
\hline
\end{tabular}




\section{C-4.1. DETAILED INITLATIVE SHEETS}

FY 1998 INITIATIVES TO ESTABLISH COMMERCIAL PRACTICES - $(\$ 000)$

\begin{tabular}{|c|c|c|c|c|c|c|c|}
\hline \multirow[b]{2}{*}{ Initiatives } & \multirow{2}{*}{$\begin{array}{c}\text { FY } 1998 \\
\text { Indirect Budget } \\
\text { Reductions }\end{array}$} & \multirow{2}{*}{$\begin{array}{c}\text { Cost Savings } \\
\text { FY 1998-2002 }\end{array}$} & \multicolumn{4}{|c|}{ FY 1998 FTE Reductions } & \multirow[b]{2}{*}{ Comments } \\
\hline & & & EX & SNE & BU & Total & \\
\hline
\end{tabular}

\begin{tabular}{|l|l|l|l|l|l|l|l|l|}
\hline HANFORD FIRE DEPARTMENT & & & & & & \\
\hline $\begin{array}{l}\text { Reduce material costs for chemical and biological } \\
\text { equipment }\end{array}$ & & & & & \\
\hline CONTRACTS & & & & & & & \\
\hline $\begin{array}{l}\text { Revise the current subcontract to enable DynCorp Tri- } \\
\text { Cities Services, Inc. to undertake commercial work by } \\
\text { September 30, 1998. }\end{array}$ & & & & & \\
\hline
\end{tabular}




\section{C-4.2. DETAILED INITIATIVE SHEETS}

\section{FY 1998 INITIATIVES TO INTEGRATE INFRASTRUCTURE - (\$000)}

\begin{tabular}{|c|c|c|c|c|c|c|c|}
\hline \multirow[b]{2}{*}{ Initiatives } & \multirow{2}{*}{$\begin{array}{c}\text { FY } 1998 \\
\text { Indirect Budget } \\
\text { Reductions }\end{array}$} & \multirow{2}{*}{$\begin{array}{l}\text { Cost Savings } \\
\text { FY 1998-2002 }\end{array}$} & \multicolumn{4}{|c|}{ FY 1998 FTE Reductions } & \multirow[b]{2}{*}{ Comments } \\
\hline & & & EX & SNE & BU & Total & \\
\hline
\end{tabular}

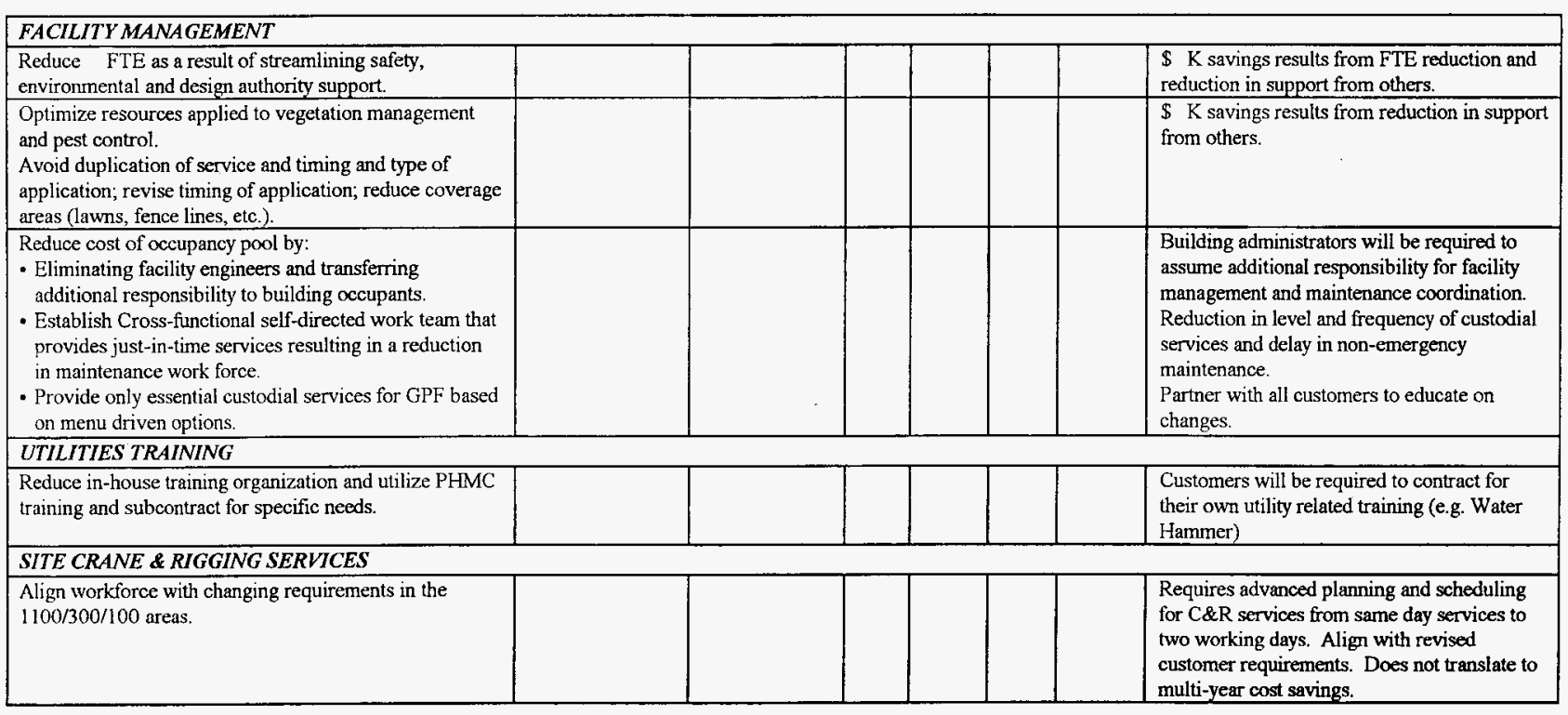




\section{C-4.2. DETAILED INITIATIVE SHEETS}

FY 1998 INITIATIVES TO INTEGRATE INFRASTRUCTURE - (\$000)

\begin{tabular}{|c|c|c|c|c|c|c|c|}
\hline \multirow[b]{2}{*}{ Initiatives } & \multirow{2}{*}{$\begin{array}{c}\text { FY 1998 } \\
\text { Indirect Budget } \\
\text { Reductions }\end{array}$} & \multirow{2}{*}{$\begin{array}{l}\text { Cost Savings } \\
\text { FY 1998-2002 } \\
\end{array}$} & \multicolumn{4}{|c|}{ FY 1998 FTE Reductions } & \multirow[b]{2}{*}{ Comments } \\
\hline & & & $\mathbf{E X}$ & SNE & BU & Total & \\
\hline
\end{tabular}

\section{SITE FABRICATION SERVICES}

Eliminate associated with reduced work scope and reduce direct charging indirect activities. Eliminate position and spread responsibilities to other

\section{managers.}

\section{WATER OPERATIONS}

Replace pumps and motors in 300 area oversized for current and future requirements. Reduces pressure fluctuations in the 300 Area and saves energy and

reduces maintenance requirements.

Replace building 312 River Pumps:

Costbenefit analysis - 12 mo. payoff

I pump in FY98 (replace a 450hp pump with one 40hp pump and one 50hp pump)

Replace building 315 Export Pumps:

Cost/benefit analysis -24 mo. Payof

I pump in FY98

\section{ELECTRICAL UTILITIES}

Reduce energy consumption by identifying and

removing/exchanging dual transformer configuration where facility mission no longer requires redundancy. Removing two transformers in the 200 East Area and exchange 5 .

Reduce total site electrical loads and reduce substation maintenance costs by closing down substations in the 100 Area.

Deactivate 151D, 151B, and 165KE substations by 9/30/98.

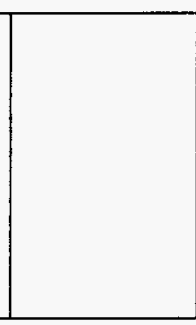

\begin{tabular}{|l|l|l|l|l|l|l|l|l|l}
\hline & & & & \\
\hline
\end{tabular}

Align with revised customer requirements Does not translate to multi-year cost savings.

\section{FLEET OPERATIONS}




\section{C-4.2. DETAILED INITIATIVE SHEETS}

FY 1998 INITIATIVES TO INTEGRATE INFRASTRUCTURE - (\$000)

\begin{tabular}{|c|c|c|c|c|c|c|c|}
\hline \multirow[b]{2}{*}{ Initiatives } & \multirow{2}{*}{$\begin{array}{c}\text { FY } 1998 \\
\begin{array}{c}\text { Indirect Budget } \\
\text { Reductions }\end{array}\end{array}$} & \multirow{2}{*}{$\begin{array}{l}\text { Cost Savings } \\
\text { FY 1998-2002 }\end{array}$} & \multicolumn{4}{|c|}{ FY 1998 FTE Reductions } & \multirow[b]{2}{*}{ Comments } \\
\hline & & & EX & SNE & BU & Total & \\
\hline
\end{tabular}

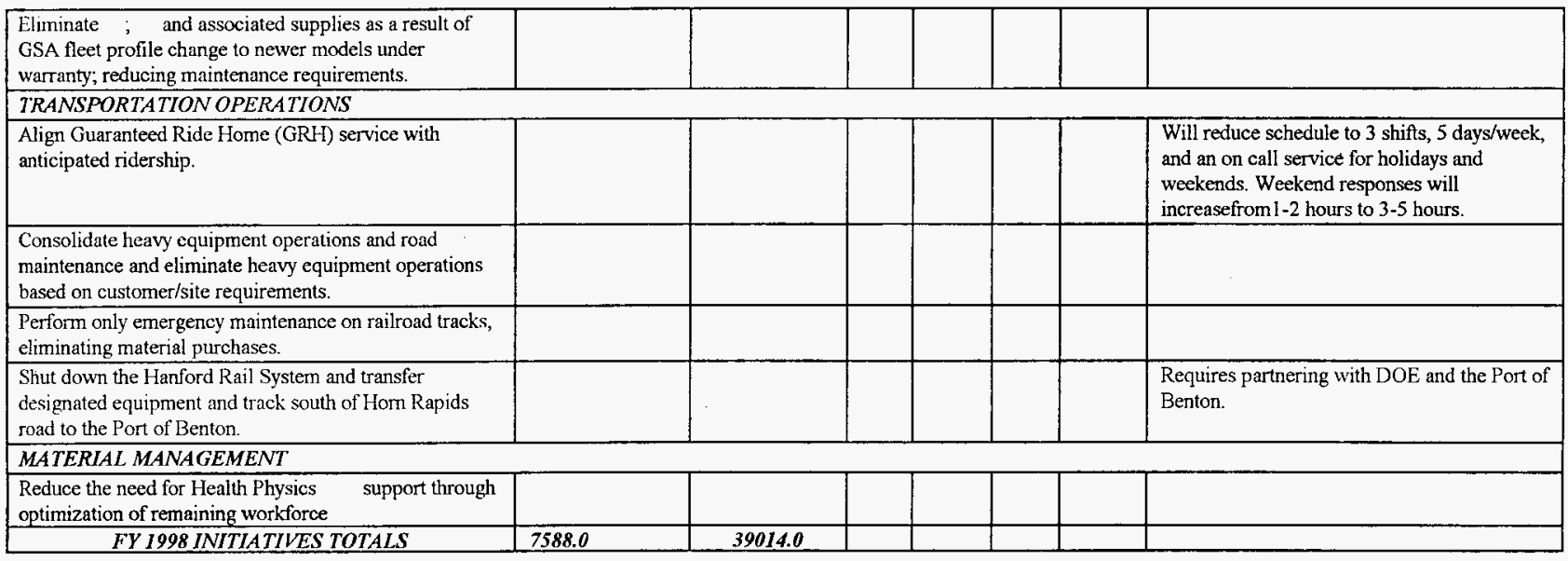




\section{C-5. FY 1998 DETAILED INITIATIVE SCHEDULE}

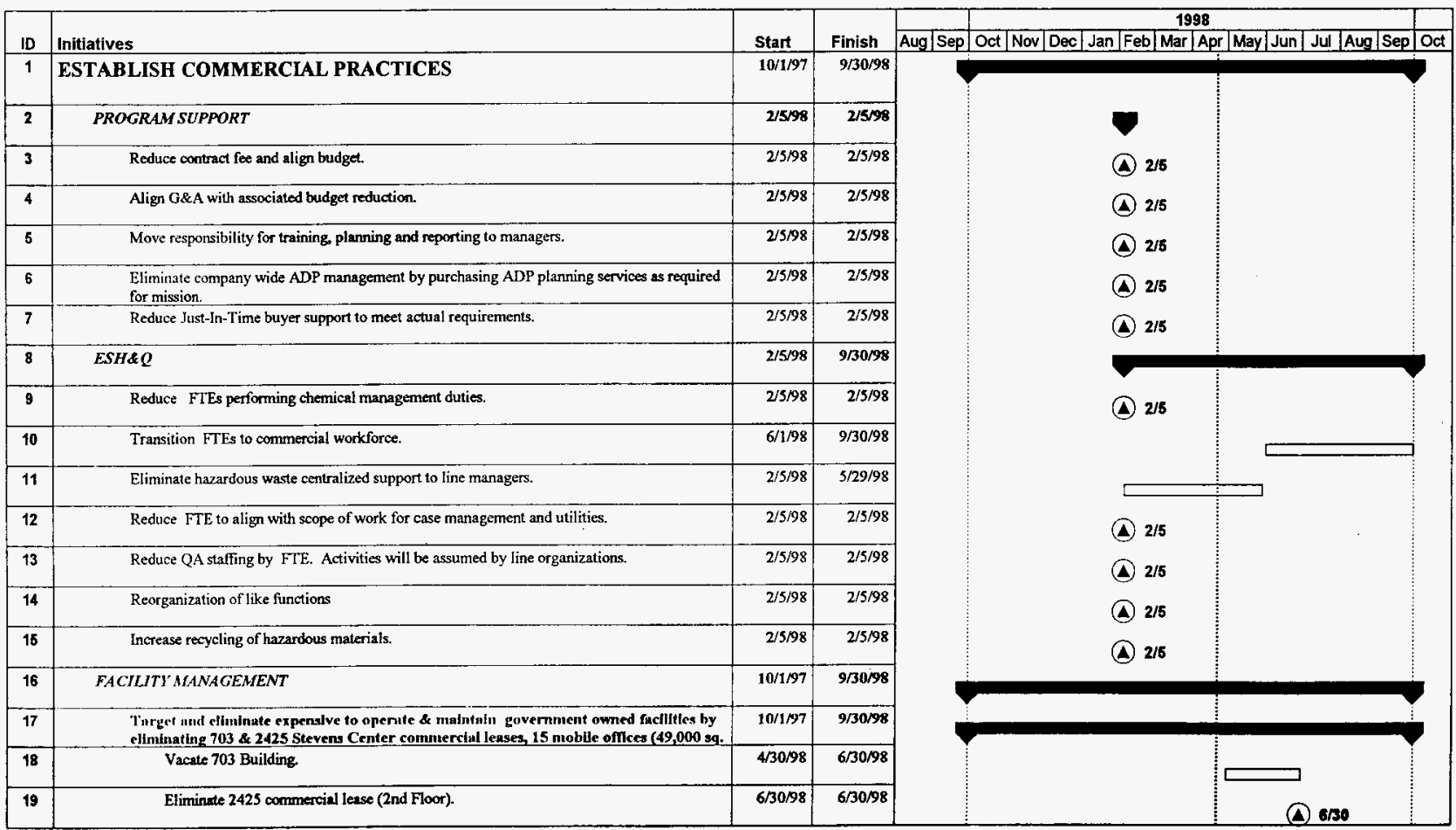

Portions of this page may have blanks $\alpha$ missing information due to the information being Company Sensitive and/or Business Proprietary

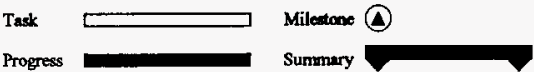

C-14 


\section{C-5. FY 1998 DETARLED INITIATIVE SCHEDULE}

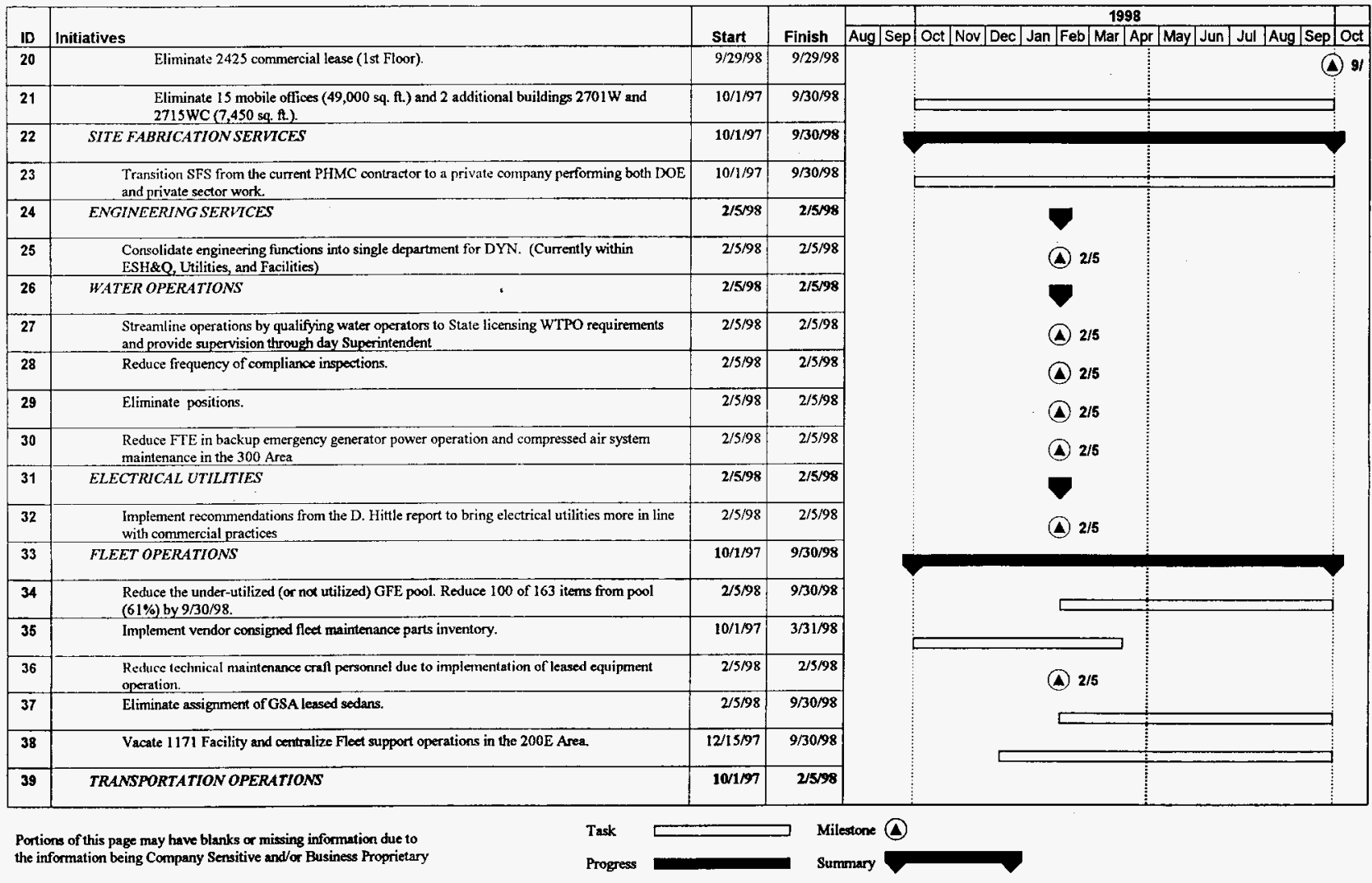




\section{C-5. FY 1998 DETAILED INITIATIVE SCHEDULE}

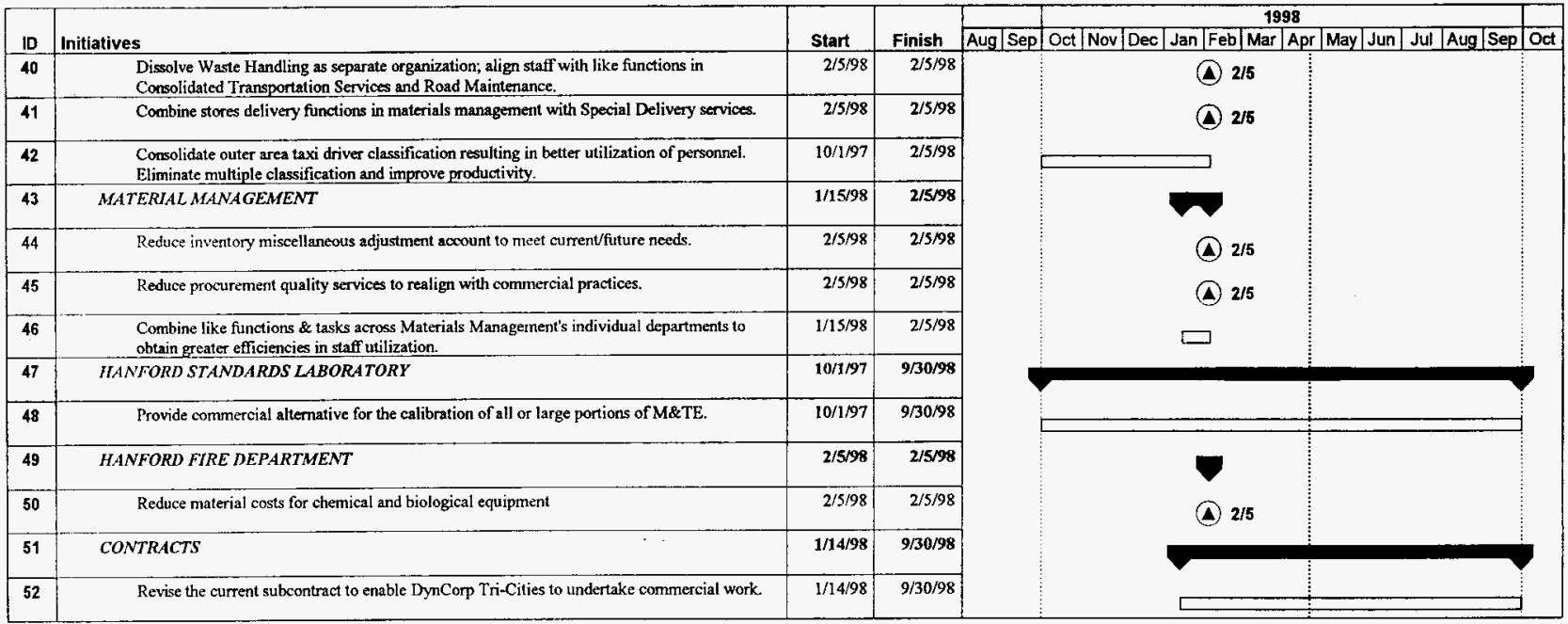

Portions of this page may have blanks or missing information the to the information being Company Sensitive and/or Business Proprietary

Scheduler: Clinton D. (Clint) Donley

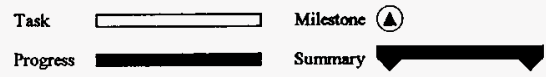

C-16 
(7) आ00:1K

6riapdo

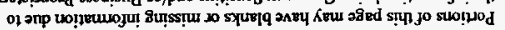

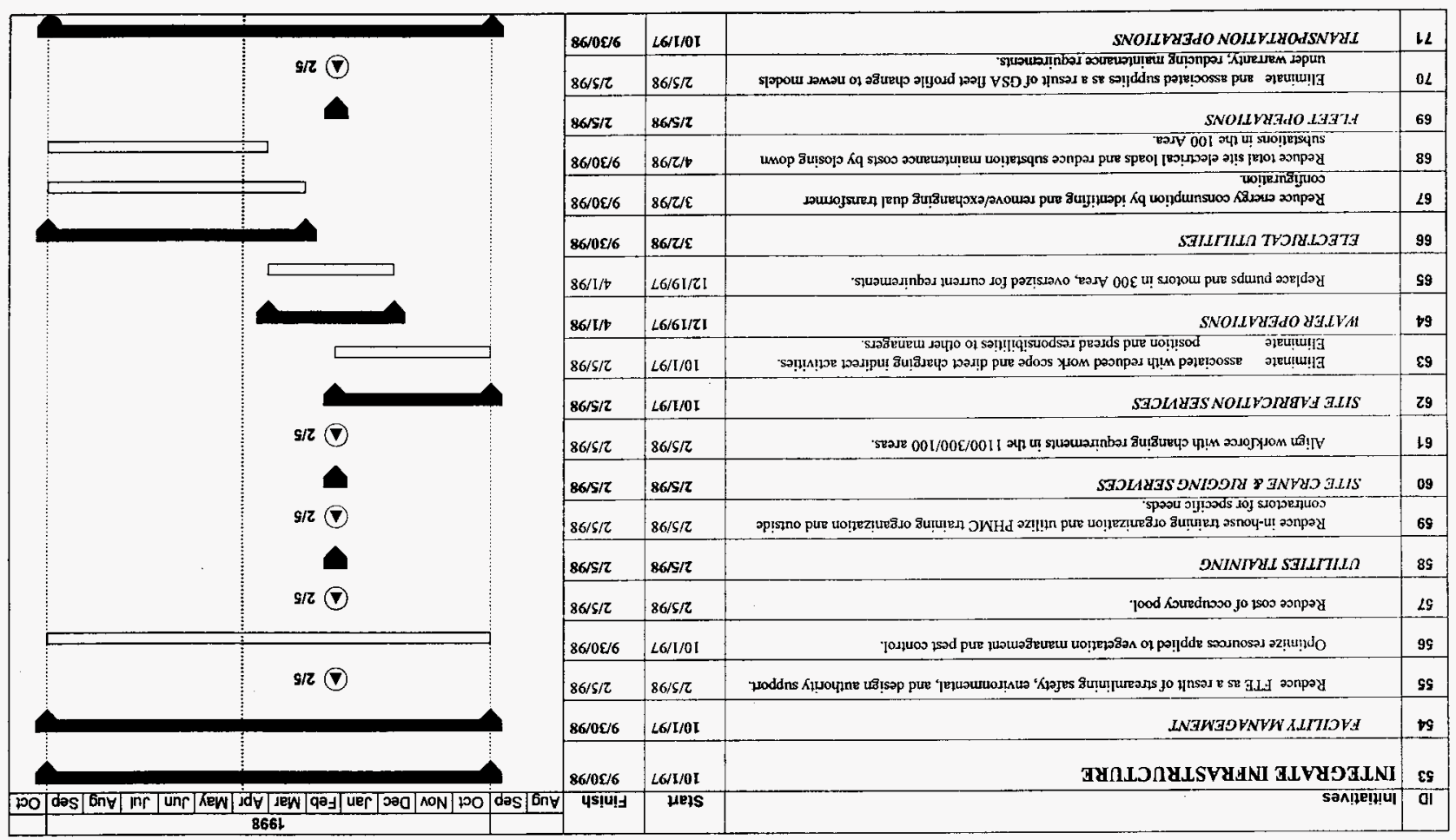

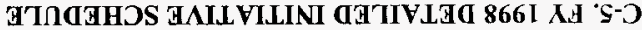




\section{C-5. FY 1998 DETAILED INITIATIVE SCHEDULE}

\begin{tabular}{|c|c|c|c|c|c|c|c|c|c|c|c|c|c|}
\hline \multirow[b]{2}{*}{ ID } & \multirow[b]{2}{*}{ Initiatives } & \multirow[b]{2}{*}{ Start } & \multirow[b]{2}{*}{ Finish } & \multirow[b]{2}{*}{ Aug } & \multirow[b]{2}{*}{ Sep } & \multicolumn{7}{|c|}{1998} & \multirow[b]{2}{*}{ Oct } \\
\hline & & & & & & Oct & Nov & Dec & \begin{tabular}{|l|l|l|} 
Jan & Feb & Mar \\
\end{tabular} & Apr May Jun & Jul Aug & Sep & \\
\hline $\overrightarrow{72}$ & Align Guaranteed Ride Home (GRH) service with anticipated ridership. & $1 / 2 / 98$ & $2 / 5 / 98$ & & & & & & 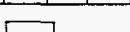 & & & & \\
\hline 73 & $\begin{array}{l}\text { Consolidate heavy equipment operations and road maintenance and eliminate heavy } \\
\text { equipment operations based on customer/site requirements. }\end{array}$ & $2 / 5 / 98$ & $2 / 5 / 98$ & & & & & & $2 / 5$ & & & & \\
\hline 74 & Perform only cmergency maintenance on railroad tracks, eliminating material purchases. & $12 / 1 / 97$ & $9 / 30 / 98$ & & & & & & & & & & \\
\hline 75 & Slut down the Hanford Site Railroad. & $10 / 1 / 97$ & $9 / 30 / 98$ & & & & & & & & & & \\
\hline 76 & MATERAL MANAGEMENT & $2 / 5 / 98$ & $2 / 5 / 98$ & & & & & & & & & & \\
\hline 77 & $\begin{array}{l}\text { Reduce the need for Healuh Physics } \\
\text { workforce. }\end{array}$ & $2 / 5 / 98$ & $2 / 5 / 98$ & & & & & & $2 / 5$ & . & & & \\
\hline
\end{tabular}

Portions of this page may have blanks or missing information due to the information being Company Sensitive and/or Business Proprietary

Scheduler: Clinton D. (Clint) Dontey
Task

Progress

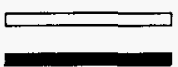

C-18
Milestone (4)

Summary 


\section{Strategic Plan for \\ Infrastructure Optimization}

D - FISCAL YEAR 1999 


\section{Strategic Plan for \\ Infrastructure Optimization}

\section{D-1. SUMMARY OF KEY FY 1999 INITIATIVES}

\section{Initiatives to Provide Services Consistent with Commercial Practices}

1. Eliminate central receiving/warehousing by implementing direct delivery to projects

2. Privatize/subcontract auto body repair

3. Privatize/subcontract solid waste and fuel delivery

4. Reduce preventive maintenance in utilities to move in line with commercial practices

5. Fully implement recommendations from the $D$. Hittle report in electrical utilities

6. Complete automation of 200 Area water system and continue to reduce electrical consumption by replacing/removing energy inefficient systems and excess electrical capacity

7. Assume control of $100 \mathrm{~K}$ water system from DESH, reducing Site cost

8. Subcontract taxi service/GRH

9. Modify contract to reflect elimination of overly restrictive and unnecessary requirements associated with nonnuclear facilities and functions

\section{Initiatives to Fully Integrate Infrastructure}

1. Continue to reduce workforce in conjunction with reductions in scope

2. Continue to reduce space, equipment, and inventory consistent with mission requirements by:

- Eliminating additional excess infrastructure in water and electrical utilities

- Eliminating 137,000 square feet of GPF office space

- Transferring management of spares to customers

- Eliminating $20 \%$ of warehousing space

- Reducing inventory by an additional $20 \%$

- Reducing fleet equipment by an additional $10 \%$

- Eliminating 50 additional pieces of equipment associated with ENCOs

3. Reduce costs to the customer and site by providing only required services

4. Vacate remaining DynCorp occupied facilities within the 1100 Area

5. Complete DynCorp reorganization

6. Complete Customer Service Agreements for all services/functions

\section{D-2. IMPACTS ASSOCIATED WITH FY 1999 INITIATIVES}

- As a result of streamlining/updating water operations in the 100 and 200 areas customers can expect a $25 \%$ reduction in cost by the beginning of FY 2001.

- Automation of water operations and closure of 200 East filter plant will significantly reduce environmental liability with the cessation of discharge to the $200 \mathrm{E}$ trencil.

- Reduction in staffing as a result of automation in water operations will result in an increase in response to emergencies from current 1 hour to $2-4$ hours.

- Automation/energy conservation measures in water operations will require \$ $\mathrm{M}$ in implementation costs.

- Vacating the 1100 Area will require $\$ M$ in implementation costs. 


\section{Strategic Plan for \\ Infrastructure Optimization}

\section{D-3. COST SAVNNGS}

An overview of originated cost, FTE reductions, and total site savings by key initiative/functional area is reflected in Table D-3.1. During the five-year cycle, cost reductions and total site savings will be adjusted to reflect new initiatives as they are identified.

Table D-3.1. Cost Savings - (\$000)

\begin{tabular}{|c|c|c|c|c|c|c|}
\hline \multirow[b]{2}{*}{ Key Inltiative/Functional Area } & \multirow{2}{*}{$\begin{array}{l}\text { FY } 1999 \text { Indirect Budget } \\
\text { Reductions }\end{array}$} & \multirow{2}{*}{$\begin{array}{l}\text { \#Cost Savings } \\
\text { FY } 1999-2002\end{array}$} & \multicolumn{4}{|c|}{ FY 1999 FTE Reductions } \\
\hline & & & EX & SNE & $\overline{\mathrm{BU}}$ & Total \\
\hline \multicolumn{7}{|c|}{ 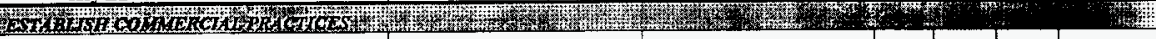 } \\
\hline \multicolumn{7}{|c|}{\begin{tabular}{|l|l|l|} 
Facilities Management & \\
\end{tabular}} \\
\hline \multicolumn{7}{|l|}{ Water Operations } \\
\hline \multicolumn{7}{|l|}{ Electrical Utilities } \\
\hline \multicolumn{7}{|l|}{ Engineering Services } \\
\hline \multicolumn{7}{|l|}{ Custodial/Maintenance Services } \\
\hline \multicolumn{7}{|l|}{ Maintenance } \\
\hline \multicolumn{7}{|l|}{ Fleet Operations } \\
\hline \multicolumn{7}{|l|}{ Transportation Operations } \\
\hline \multicolumn{7}{|l|}{ Materials Management. } \\
\hline Establish Commercial Practices Total & 1564.0 & 9373.0 & & & & \\
\hline 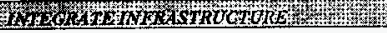 & 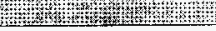 & 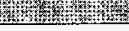 & tat & 4 & 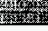 & (x) \\
\hline \multicolumn{7}{|l|}{ Water Operations } \\
\hline Integrate Infrastructure Total & 150.0 & 3002.0 & & & & \\
\hline FY 1999 TOTAL & 1714.0 & 12375.0 & & & & \\
\hline
\end{tabular}

* Savings in FY 1998 through FY 2002 include originated and non-originated cost savings escalated at $3.5 \%$ annually.

\section{D-4. FY 1999 DETAILED INITIATIVE SHEETS}

FY 1999 initiatives are listed in Tables D-4.1. and D-4.2. 
D-4.1. DETALED INITIATTVE SHEETS

FY 1999 INITIATIVES TO ESTABLISH COMMERCIAL PRACTICES - (\$000)

\begin{tabular}{|c|c|c|c|c|c|c|c|}
\hline \multirow[b]{2}{*}{ Initiatives } & \multirow{2}{*}{$\begin{array}{c}\text { FY } 1999 \\
\text { Indirect Budget } \\
\text { Reductions }\end{array}$} & \multirow{2}{*}{$\begin{array}{l}\text { Cost Savings } \\
\text { FY 1999-2002 }\end{array}$} & \multicolumn{4}{|c|}{ FY 1999 FTE Reductions } & \multirow[b]{2}{*}{ Comments } \\
\hline & & & $\mathbf{E X}$ & SNE & BU & Total & \\
\hline
\end{tabular}

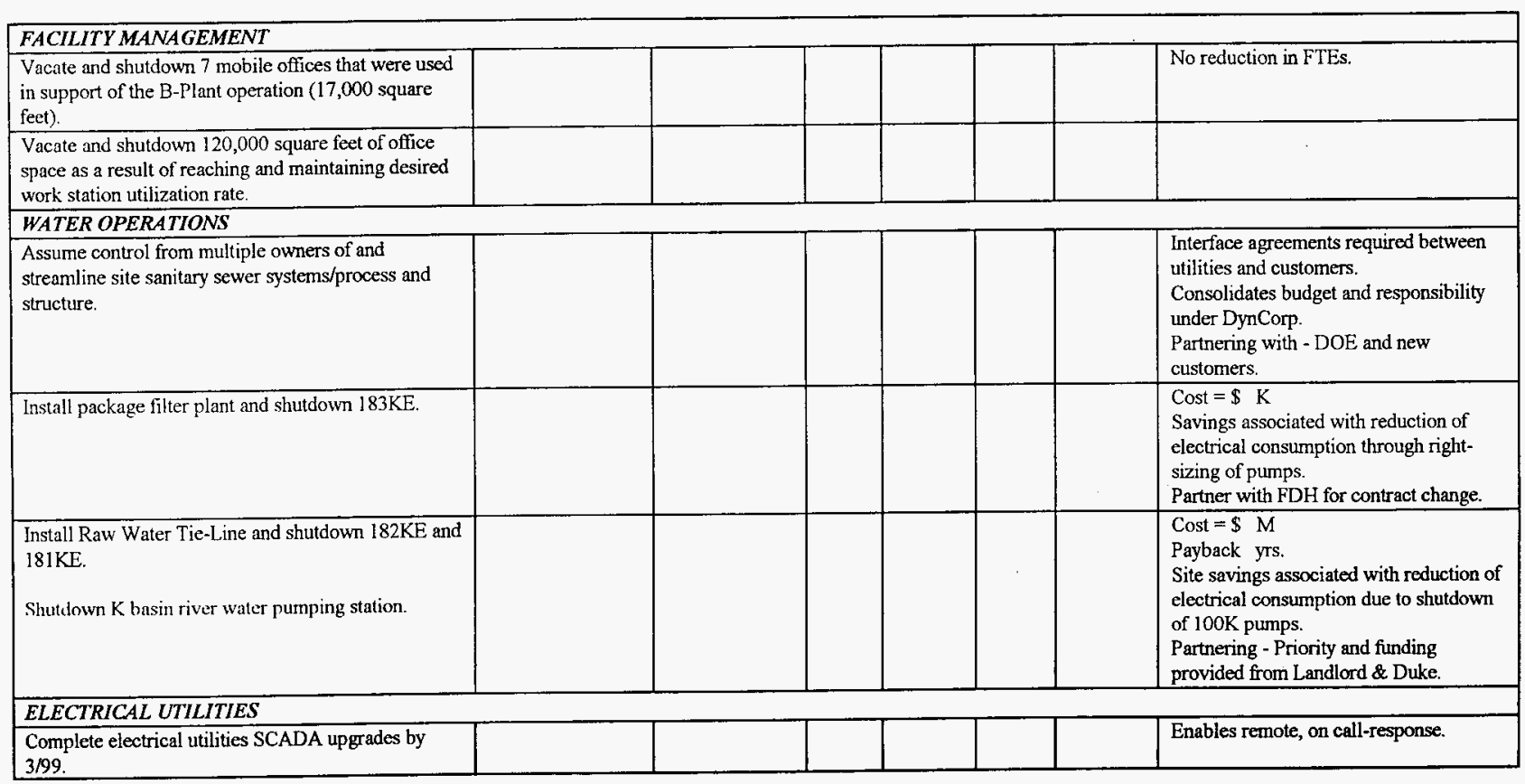


D-4.1. DETAILD INITIATIVE SHEETS

FY 1999 INITIATIVES TO ESTABLISH COMMERCIAL PRACTICES - (\$000)

\begin{tabular}{|c|c|c|c|c|c|c|c|}
\hline \multirow[b]{2}{*}{ Initjatives } & \multirow{2}{*}{$\begin{array}{c}\text { FY } 1999 \\
\text { Indirect Budget } \\
\text { Reductions }\end{array}$} & \multirow{2}{*}{$\begin{array}{l}\text { Cost Savings } \\
\text { FY } 1999-2002\end{array}$} & \multicolumn{4}{|c|}{ FY 1999 FTE Reductions } & \multirow[b]{2}{*}{ Comments } \\
\hline & & & EX & SNE & BU & Total & \\
\hline
\end{tabular}

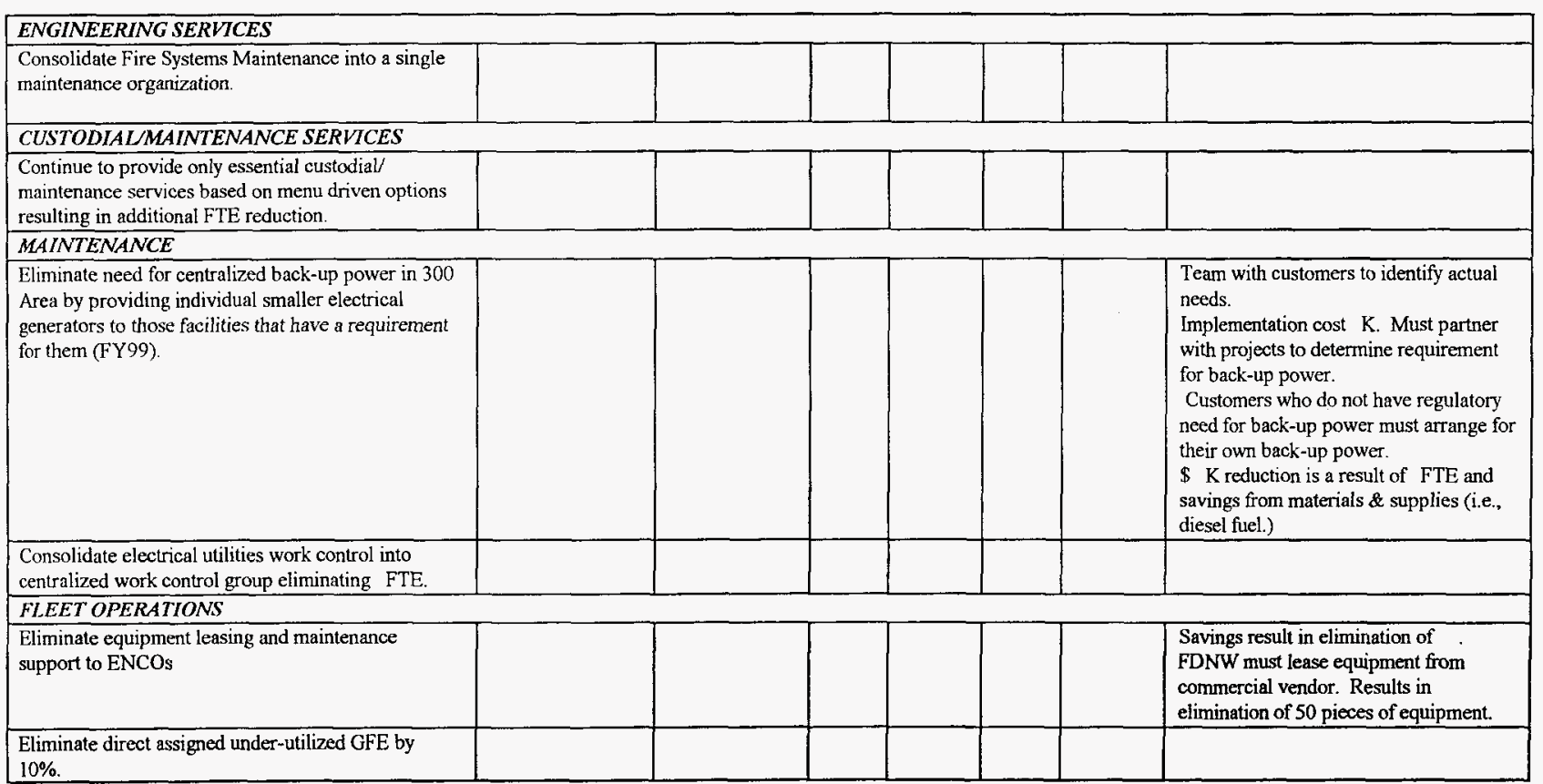




\section{D-4.1. DETAILED INITIATIVE SHEETS}

\section{FY 1999 INITIATIVES TO ESTABLISH COMMERCIAL PRACTICES - (\$000)}

\begin{tabular}{|c|c|c|c|c|c|c|}
\hline & \multirow{2}{*}{$\begin{array}{c}\text { FY } 1999 \\
\text { Indirect Budget } \\
\text { Reductions }\end{array}$} & $\begin{array}{l}\text { Cost Savings } \\
\text { FY 1999-2002 }\end{array}$ & \multicolumn{3}{|c|}{ FY 1999 FTE Reductions } \\
\cline { 4 - 5 } & Initiatives & SNE & BU & Total & Comments \\
\hline
\end{tabular}

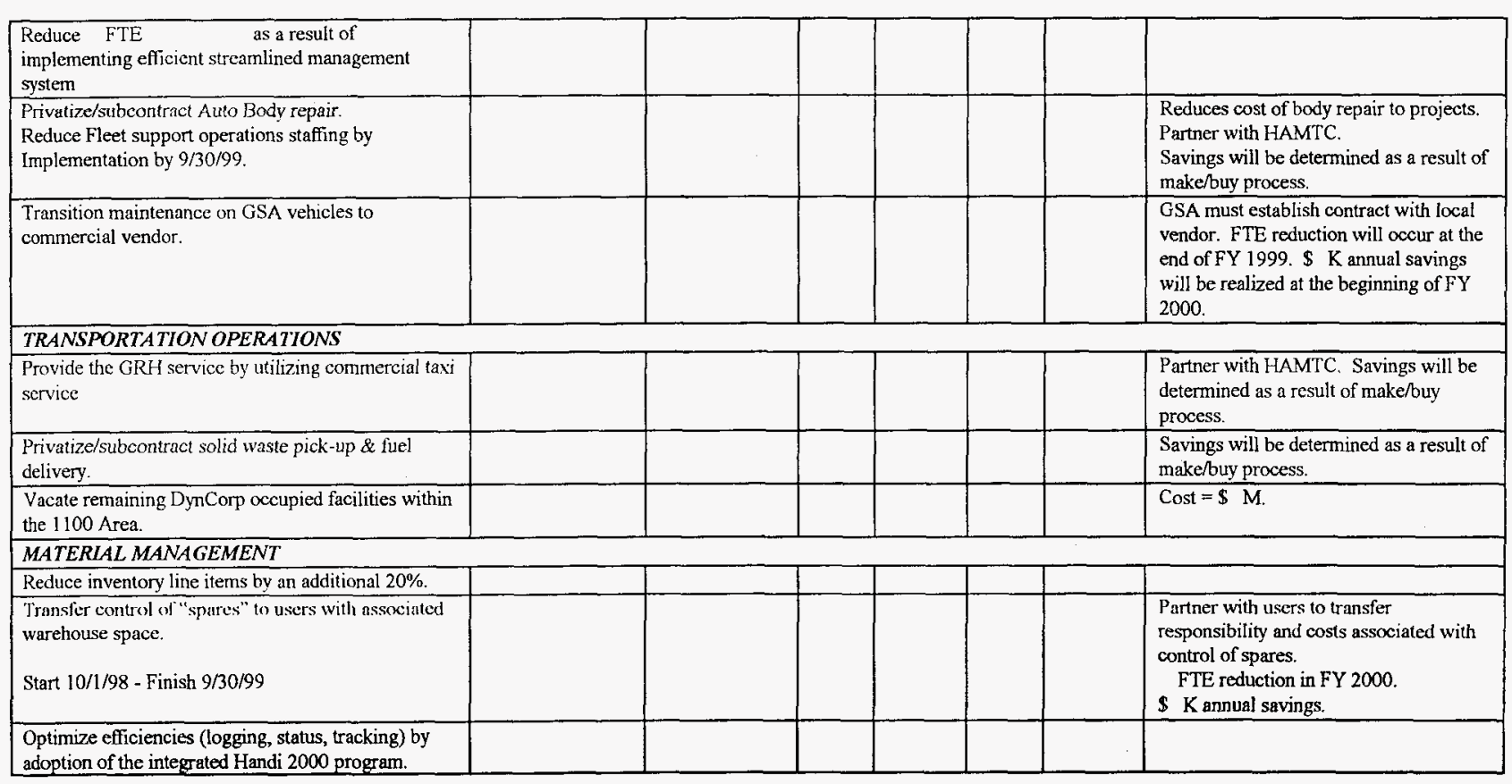


D-4.1. DETAILED INITIATIVE SHEETS FY 1999 INITIATIVES TO ESTABLISH COMMERCIAL PRACTICES - (\$000)

\begin{tabular}{|c|c|c|c|c|c|c|c|}
\hline \multirow[b]{2}{*}{ Initiatives } & \multirow{2}{*}{$\begin{array}{c}\text { FY } 1999 \\
\text { Indirect Budget } \\
\text { Reductions } \\
\end{array}$} & \multirow{2}{*}{$\begin{array}{l}\text { Cost Savings } \\
\text { FY 1999-2002 }\end{array}$} & \multicolumn{4}{|c|}{ FY 1999 FTE Reductions } & \multirow[b]{2}{*}{ Comments } \\
\hline & & & $\mathbf{E X}$ & SNE & BU & Total & \\
\hline $\begin{array}{l}\text { Reduce procurement quality services to realign with } \\
\text { commercial practices. }\end{array}$ & & & & & & & $\begin{array}{l}\text { Safety class inspection requirements } \\
\text { have been aligned with commercial } \\
\text { practices. }\end{array}$ \\
\hline
\end{tabular}




\section{D-4.2. DETAILED INITIATIVE SHEETS}

\section{FY 1999 INITIATIVES TO INTEGRATE INFRASTRUCTURE - (\$000)}

\begin{tabular}{|c|c|c|c|c|c|c|c|}
\hline \multirow[b]{2}{*}{ Initiatives } & \multirow{2}{*}{$\begin{array}{l}\text { FY } 1999 \text { Indirect } \\
\text { Budget Reductions }\end{array}$} & \multirow{2}{*}{$\begin{array}{l}\text { Cost Savings } \\
\text { FY 1999-2002 }\end{array}$} & \multicolumn{4}{|c|}{ FY 1999 FTE Reductions } & \multirow[b]{2}{*}{ Comments } \\
\hline & & & $\overline{\mathbf{E X}}$ & SNE & BU & Total & \\
\hline
\end{tabular}

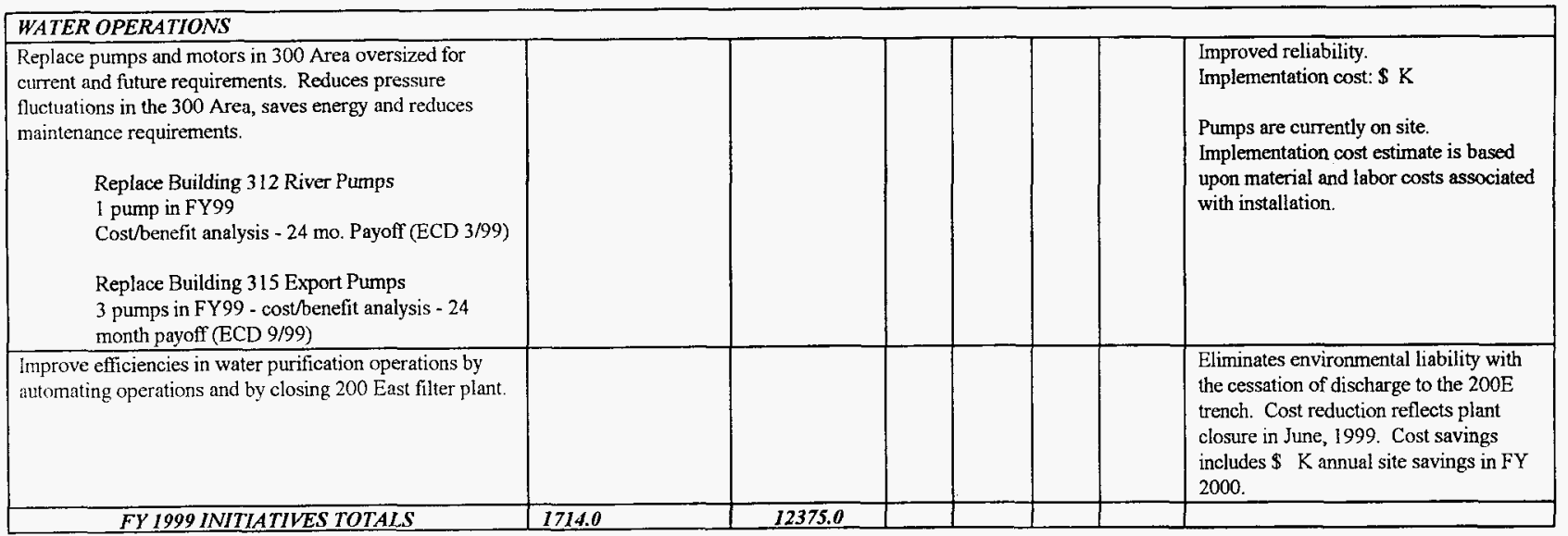




\section{D-5. FY 1999 DETAILED INITIATIVE SCHEDULE}

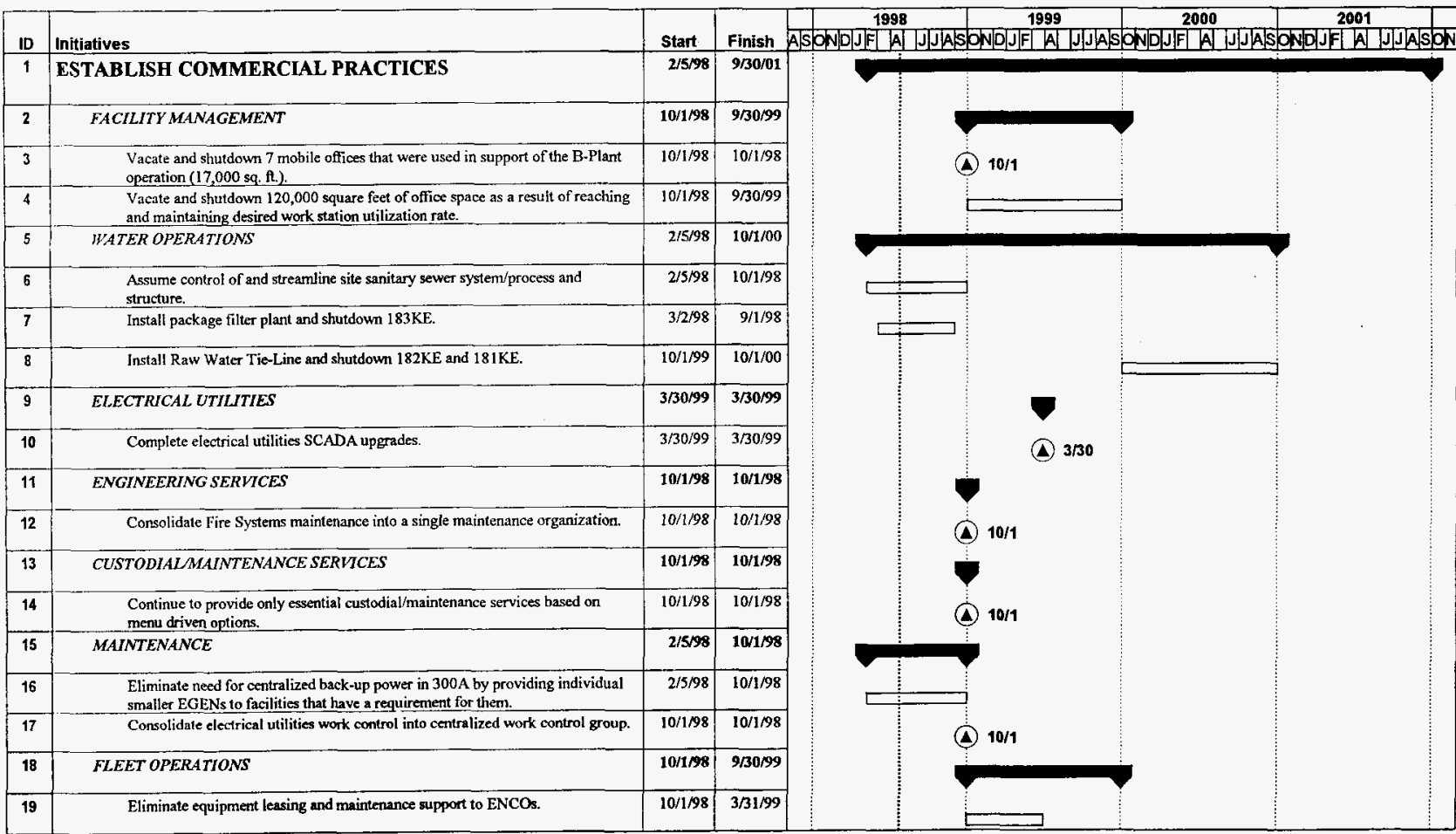

Portions of this page may have blanks or missing information due to the information being Company Sensitive and/or Business Prorietary

Scheduler: Clinton D. (Clint) Donley
Task

Progress
Milestone (4)

Summary 


\section{D-5. FY 1999 DETAILED INITIATIVE SCHEDULE}

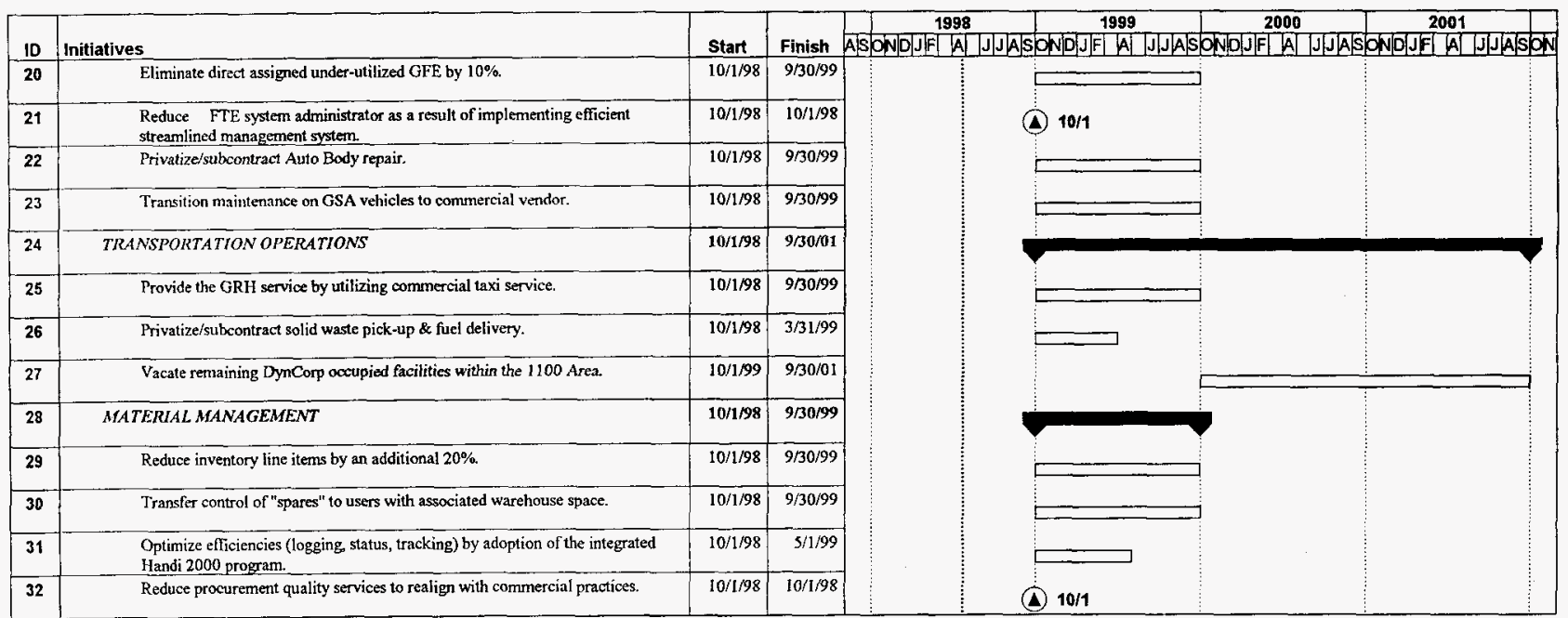

Portions of this page may have blanks or missing information due to the information being Company Sensitive and/or Business Prorietary

Schedules: Clinton D. (Clint) Donley
Task $\square$ Milestone (4)

Progress Summary

D-10 


\section{D-5. FY 1999 DETAILED INITIATIVE SCHEDULE}

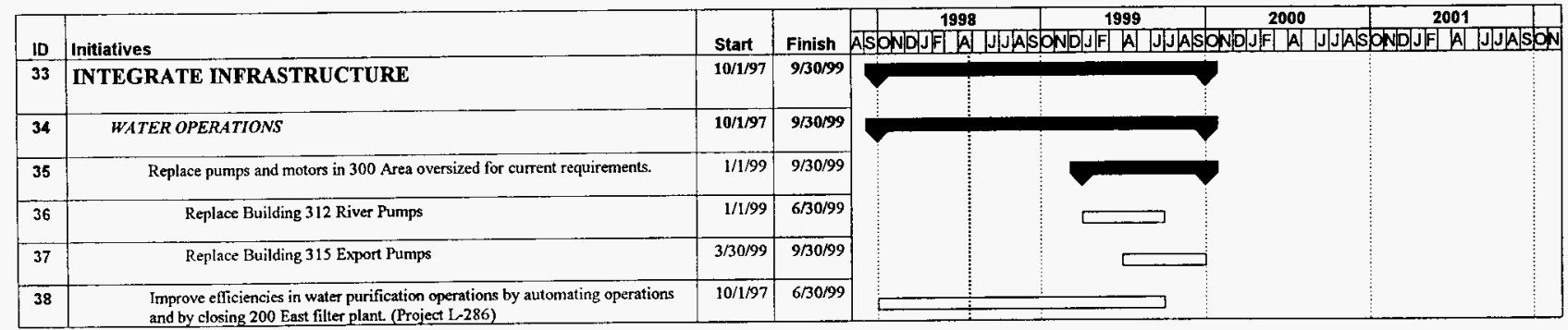

Portions of this page may have blanks or missing information due to the information being Company Sensitive and/or Business Prorietary

Scheduler: Clinton D. (Clint) Donley $\begin{array}{lll}\text { Task } & \text { Milestone (4) } \\ \text { Progress } & \text { Summary }\end{array}$

D-11 


\section{Strategic Plan for \\ Infrastructure Optimization}

E - FISCAL YEAR 2000+ 


\section{Strategic Plan for \\ Infrastructure Optimization}

\section{E-1. SUMMARY OF KEY FY 2000+ INITIATIVES}

\section{Commercial Practices}

1. Continue to reduce/eliminate unnecessary overly restrictive requirements to be more in line with commercial practices

2. Continue to reduce energy consumption by replacing and/or removing energy inefficient pumps and oversized transformers

3. HANDI 2000 fully integrated

\section{Integration}

1. Continue to reduce workforce in conjunction with reductions in scope

2. Continue to reduce space, equipment, and inventory consistent with mission requirements

3. Insure infrastructure is postured to support TWRS privatization

4. All services are privatized/subcontracted - DynCorp restructured to support new way of doing business

\section{E-2. IMPACTS ASSOCIATED WITH FY 2000+ INITIATIVES}

- Automation in water operations will require $\$$ million in implementation costs.

- 100 Area response time for water line breaks will increase from 2-4 hours to 4-6 hours during day shift and from 3-6 hours to 5-10 hours during off shift.

\section{E-3. COST SAVINGS}

An overview of originated cost, FTE reductions, and total site savings by key initiative/functional area is reflected in Table E-3.1. During the five-year cycle, cost reductions and total site savings will be adjusted to reflect new initiatives as they are identified.

Table E-3.1. Cost Savings-(S000)

\begin{tabular}{|c|c|c|c|c|c|c|}
\hline \multirow[b]{2}{*}{ Key Initiative/Functional Area } & \multirow{2}{*}{$\begin{array}{c}\text { FY 2000-2002 } \\
\text { Indirect Budget Reductions }\end{array}$} & \multirow{2}{*}{$\begin{array}{l}\text { *Cost Savings } \\
\text { FY 2000-2002 } \\
\end{array}$} & \multicolumn{4}{|c|}{ FY 2000+ FTE Reductions } \\
\hline & & & EX & SNE & BU & Total \\
\hline \multicolumn{7}{|c|}{ HST } \\
\hline \multicolumn{7}{|c|}{\begin{tabular}{|l|l|l|} 
& \\
\end{tabular}} \\
\hline Establish Commercial Practices Total & 400.0 & 1242.0 & & & & \\
\hline \multicolumn{7}{|c|}{ 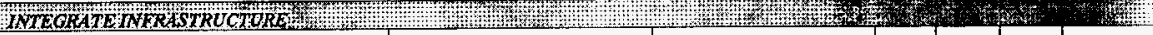 } \\
\hline \multicolumn{7}{|c|}{\begin{tabular}{|l|l|} 
Water Operations & \\
\end{tabular}} \\
\hline \multicolumn{7}{|l|}{ Material Management } \\
\hline Integrate Infrastructure Total & 2200.0 & 7113.0 & & & & \\
\hline FY $2000+$ TOTAL & 2600.0 & 8355.0 & & & & \\
\hline
\end{tabular}

- Savings in FY 1998 through FY 2002 include originated and non-originated cost savings escalated at 3.5\% annually.

\section{E-4. FY 2000+ DETALED INITIATIVE SHEETS}

FY $2000+$ initiatives are listed in Tables E-4.1. and E-4.2. 


\section{E-4.1. DETAILED INITIATIVE SHEETS}

FY 2000+ INITIATIVES TO ESTABLISH COMMERCIAL PRACTICES - (\$000)

\begin{tabular}{|c|c|c|c|c|c|c|c|}
\hline \multirow[b]{2}{*}{ Initiatives } & \multirow{2}{*}{$\begin{array}{l}\text { FY 2000-2002 } \\
\text { Indirect Budget } \\
\text { Reductions }\end{array}$} & \multirow{2}{*}{$\begin{array}{c}\text { Cost Savings } \\
\text { FY 2000-2002 }\end{array}$} & \multicolumn{4}{|c|}{ FY 2000+ FTE Reductions } & \multirow[b]{2}{*}{ Comments } \\
\hline & & & EX & SNE & BU & Total & \\
\hline
\end{tabular}

\section{WATER OPERATIONS}

Automate 300 Area Water Plant and operate from

$283 \mathrm{~W}$ resulting in reduction of FTEs in FY01. 
E-4.2. DETAILED INITIATIVE SHEETS

FY 2000+ INITIATIVES TO INTEGRATE INFRASTRUCTURE - (\$000)

\begin{tabular}{|c|c|c|c|c|c|c|c|}
\hline \multirow[b]{2}{*}{ Initiatives } & \multirow{2}{*}{$\begin{array}{l}\text { FY 2000-2002 Indirect } \\
\text { Budget Reductions }\end{array}$} & \multirow{2}{*}{$\begin{array}{l}\text { Cost Savings } \\
\text { FY 2000-2002 }\end{array}$} & \multicolumn{4}{|c|}{ FY 2000+ FTE Reductions } & \multirow[b]{2}{*}{ Comments } \\
\hline & & & EX & SNE & BU & Total & \\
\hline
\end{tabular}

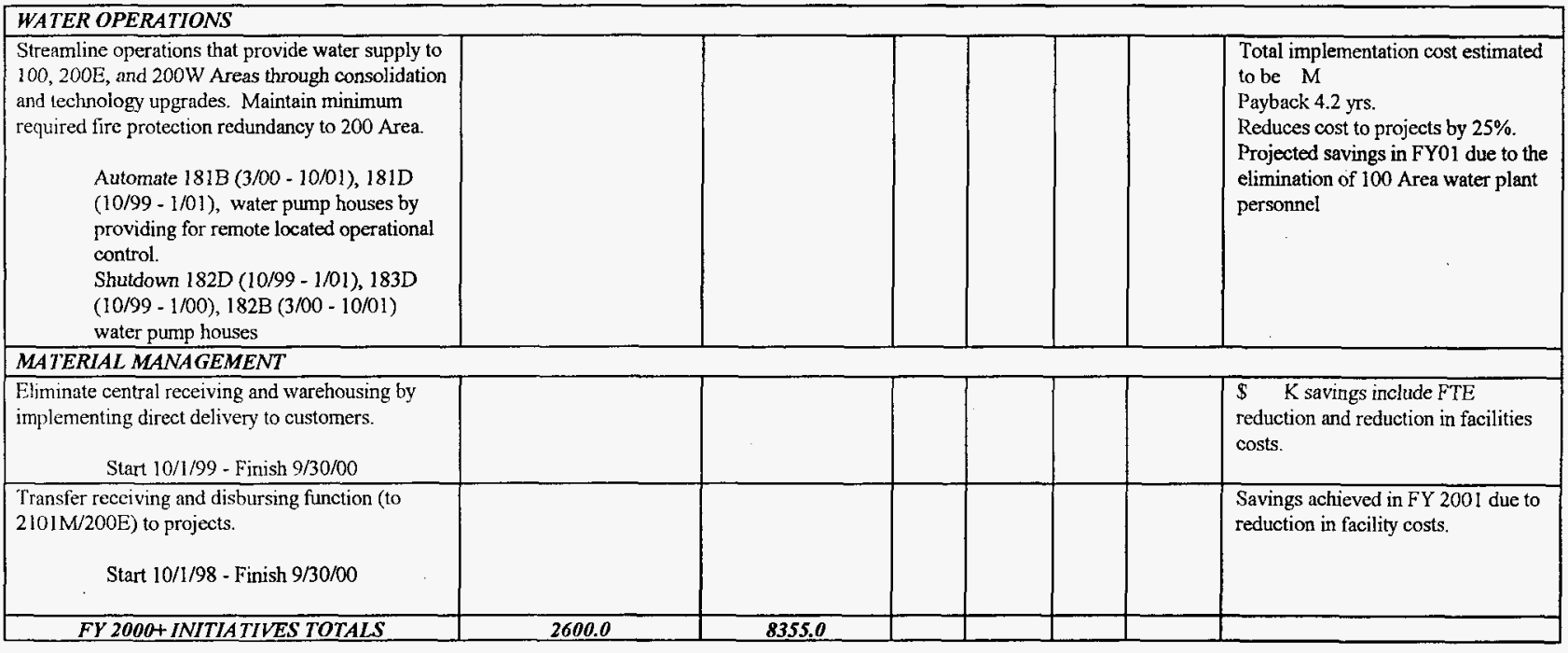




\section{E-5. FY 2000+ DETAILED INITIATTVE SCHEDULE}

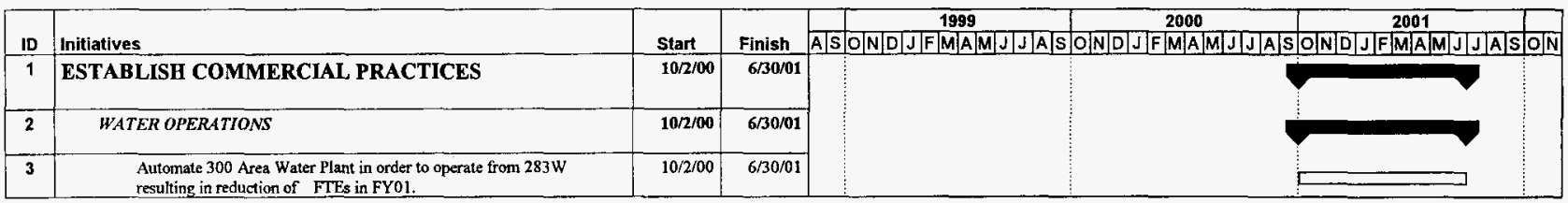

Portions of this page may have blanks or missing information due to the information being Company Sensitive and/or Business Proprietary

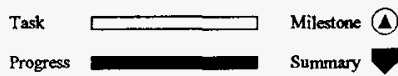

E-5 


\section{E-5. FY 2000+ DETAILED INITIATIVE SCHEDULE}

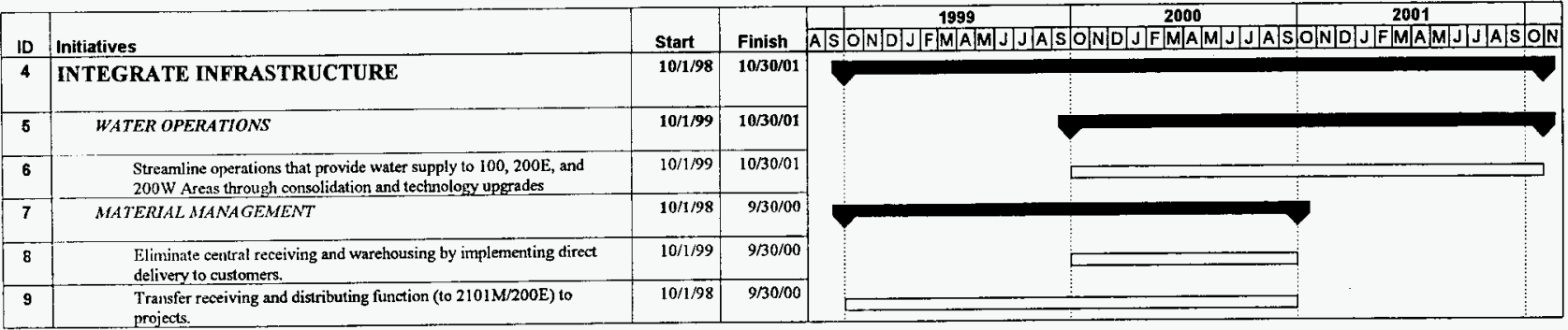

Portions of this page may have blanks or missing information due to the information being Company Sensitive and/or Business Proprietary

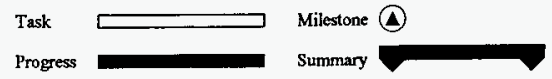

$E-6$ 


\title{
Strategic Plan for \\ Infrastructure Optimization
}

\author{
F - MULTI-YEAR SCHEDULE
}




\section{F-1. MULTI-YEAR SCHEDULE}

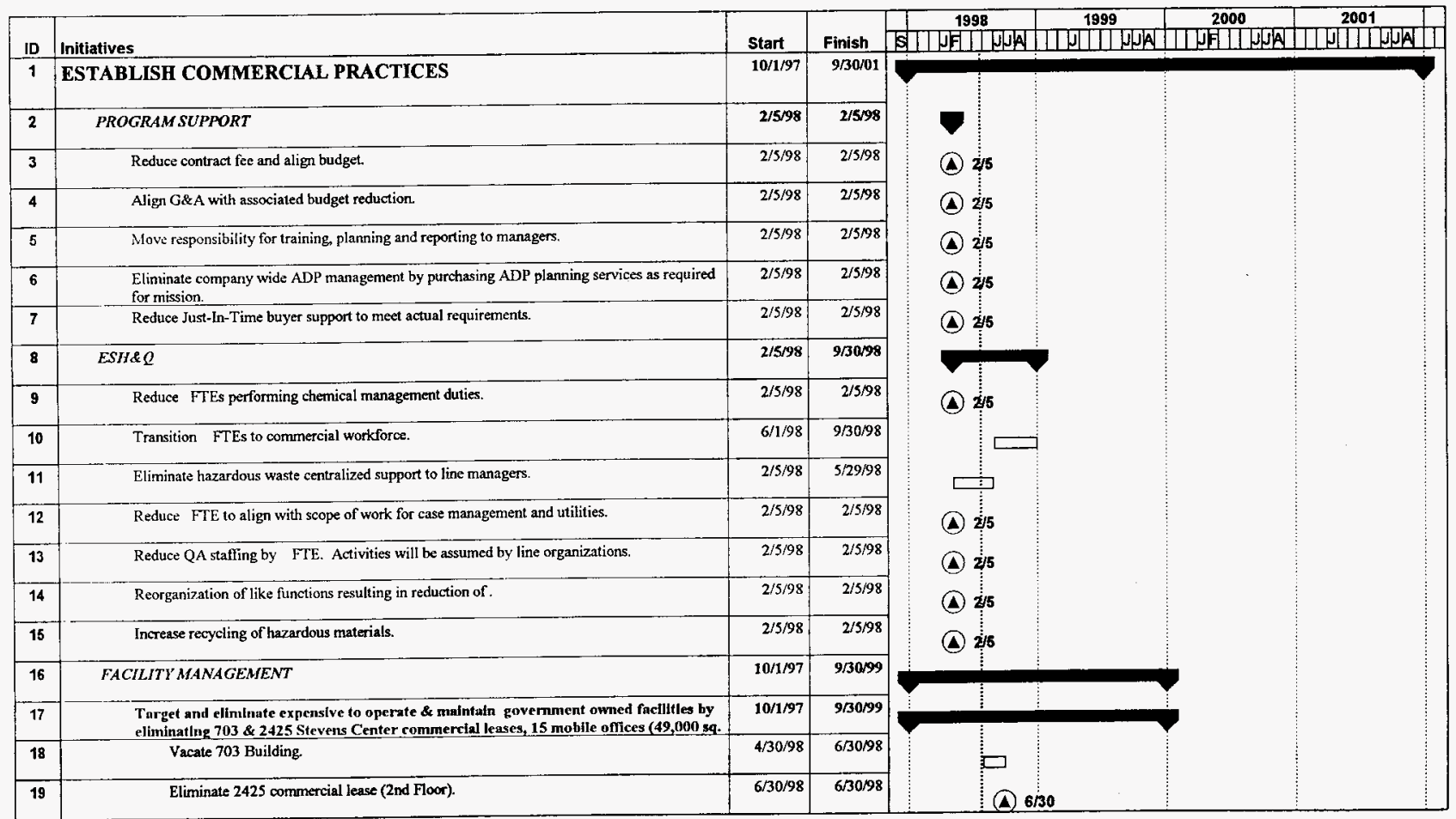

Portions of this page may have blankes or missing information due to the information being Company Sensitive and/or Business Proprietary

Scheduler: Clinton D. (Clint) Donley

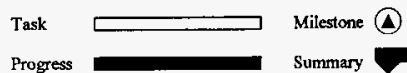

F-2 


\section{F-1. MULTI-YEAR SCHEDULE}

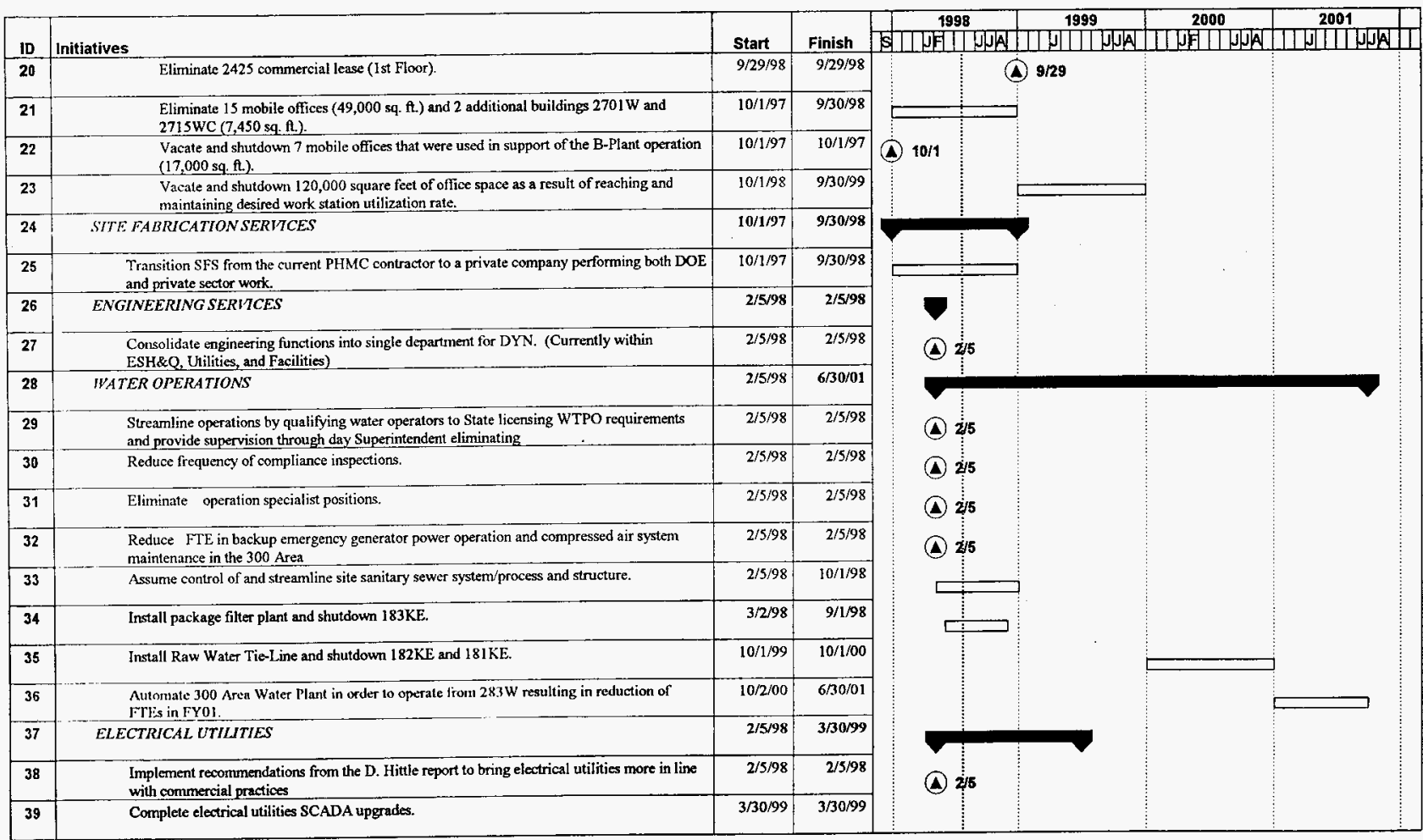

Portions of this page may have blankes or missing information due to the information being Company Sensitive and/or Business Proprietary

Schetuler: Clinton D. (Clint) Donley
Task

Progress
Milestone (A)

Summary 


\section{F-1. MULTI-YEAR SCHEDULE}

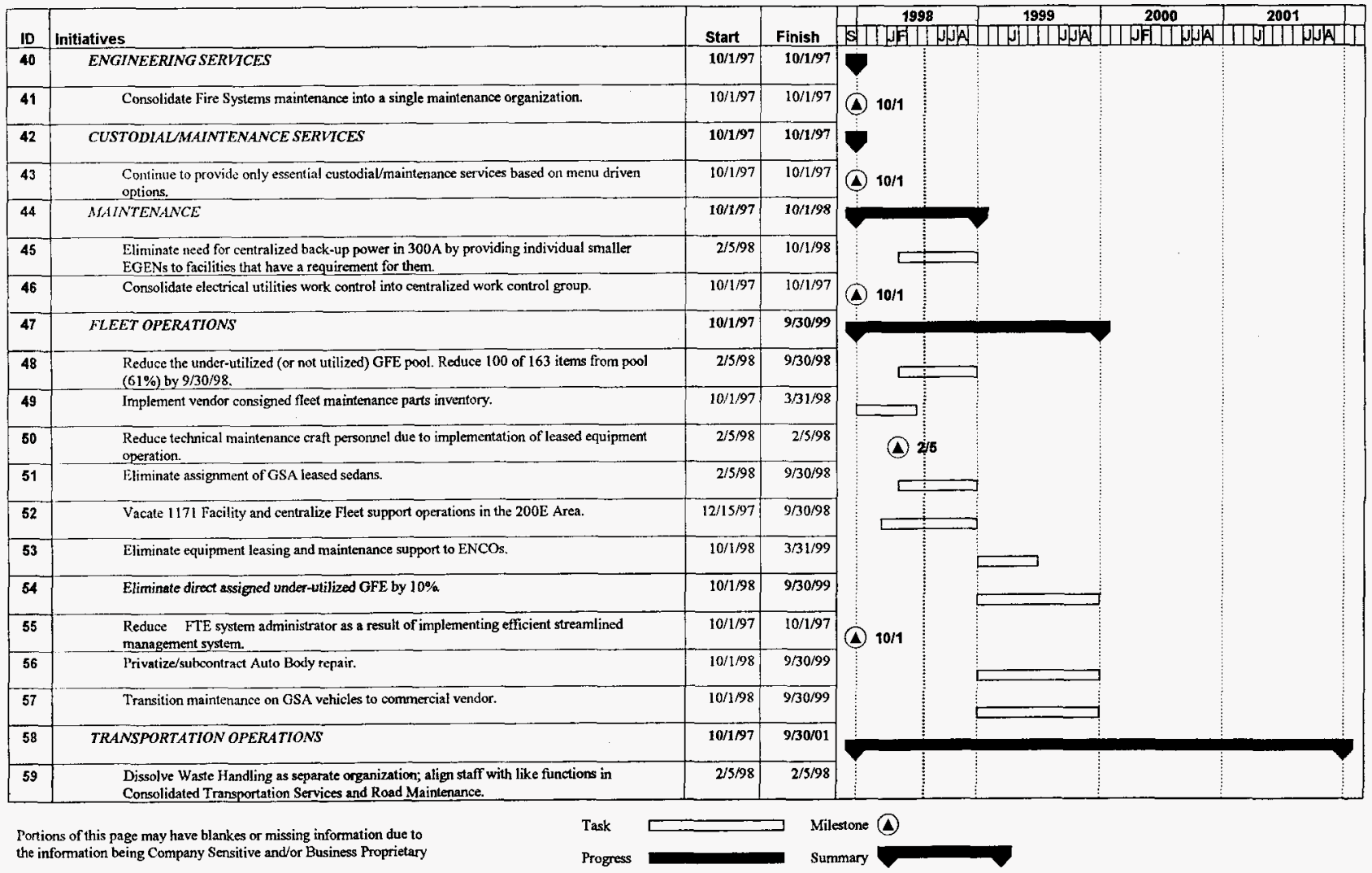




\section{F-1. MULTI-YEAR SCHEDULE}

\begin{tabular}{|c|c|c|c|c|c|c|c|c|}
\hline \multirow[b]{2}{*}{10} & \multirow[b]{2}{*}{ Initiatives } & \multirow[b]{2}{*}{ Start } & \multirow[b]{2}{*}{ Finish } & \multicolumn{2}{|c|}{1998} & 1999 & 2000 & 2001 \\
\hline & & & & S.DTH & WNA & IN]DHJA & WFIDNNA & JIIINAA \\
\hline 60 & Combine stores delivery functions in materials management with Special Delivery services. & $2 / 5 / 98$ & $2 / 5 / 98$ & & 5 & & & \\
\hline 61 & $\begin{array}{l}\text { Consolidate outer area taxi driver classification resulting in better utilization of personnel. } \\
\text { Eliminate multiple classification and improve productivity. }\end{array}$ & $10 / 1 / 97$ & $2 / 5 / 98$ & & & & & \\
\hline 62 & Provide the GRH service by utilizing commercial taxi servicc. & $10 / 1 / 98$ & $9 / 30 / 99$ & & & & & \\
\hline 63 & Privatize/subcontract solid waste pick-up \& fuel delivery. & $10 / 1 / 98$ & $3 / 31 / 99$ & & & & & \\
\hline 64 & Vacate remaitring DynCorp occupied facilities within the 1100 Area. & $10 / 1 / 99$ & $9 / 30 / 01$ & & & & & \\
\hline 65 & MATERIAL MANAGEAIENT & $10 / 1 / 97$ & $9 / \longdiv { 3 0 / 9 9 }$ & & & & & \\
\hline 66 & Reduce inventory miscellaneous adjustment account to meet current/future needs. & $2 / 5 / 98$ & $2 / 5 / 98$ & & & & & \\
\hline 67 & Reduce procurement quality services to realign with commercial practices. & $2 / 5 / 98$ & $2 / 5 / 98$ & & & & & \\
\hline 68 & $\begin{array}{l}\text { Combine like functions \& tasks across Materials Management's individual departments to } \\
\text { obtain greater efficiencies in staff utilization. }\end{array}$ & $1 / 15 / 98$ & $2 / 5 / 98$ & 口 & & & & \\
\hline 69 & Reduce inventory line items by an additional $20 \%$ & $10 / 1 / 98$ & $9 / 30 / 99$ & & & & & \\
\hline 70 & Transfer control of "spares" to users with associated warehouse space. & $10 / 1 / 98$ & $9 / 30 / 99$ & & & & & \\
\hline 71 & $\begin{array}{l}\text { Optimize efficiencies (logging, status, tracking) by adoption of the integrated Handi } 2000 \\
\text { program. }\end{array}$ & $10 / 1 / 98$ & $5 / 1 / 99$ & & & & & \\
\hline 72 & Reduce procurement quality services to realign with commercial practices. & $10 / 1 / 97$ & $10 / 1 / 97$ & (A) $10 / 1$ & & & & \\
\hline 73 & HANFORD STANDARDS LABORATORY & $10 / 1 / 97$ & $9 / 30 / 98$ & & & & & \\
\hline 74 & Provide commercial alternative for the calibration of all or large portions of M\&TE. & $10 / 1 / 97$ & $9 / 30 / 98$ & & & & & \\
\hline 75 & HANFORD FIRE DEPARTMENT & $2 / 5 / 98$ & $2 / 5 / 98$ & & & & & \\
\hline 76 & Reduce material costs for chemical and biological equipment & $2 / 5 / 98$ & $2 / 5 / 98$ & & & & & \\
\hline 77 & CONTRACTS & $1 / 14 / 98$ & 9/30/98 & & & & & \\
\hline 78 & Revise the current subcontract to enable DynCorp Tri-Cities to undertake commercial work. & $1 / 14 / 98$ & $9 / 30 / 98$ & & & & & \\
\hline
\end{tabular}

Portions of this page may have blankes or missing information due to the information being Company Sensitive and/or Business Proprietary

Scheduler: Clinton D. (Clint) Donley

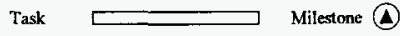

Progress

Summary 


\section{F-1. MULTI-YEAR SCHEDULE}

\begin{tabular}{|c|c|c|c|c|c|c|c|}
\hline & & & & 1998 & 1999 & 2000 & 2001 \\
\hline ID & Initiatives & Start & Finish & DFDWWA & जIIDNA & WFIJNA & WIIINWA \\
\hline 79 & INTEGRATE INFRASTRUCTURE & $10 / 1 / 97$ & $10 / 30 / 01$ & & & & \\
\hline 80 & FACILITY MANAGEMENT & $10 / 1 / 97$ & 9/30/98 & & & & \\
\hline 81 & Reduce FTE as a result of streamlining safety, environmental, and design authority support. & $2 / 5 / 98$ & $2 / 5 / 98$ & & & & \\
\hline 82 & Optimize resources applied to vegetation management and pest control. & $10 / 1 / 97$ & $9 / 30 / 98$ & & & & \\
\hline 83 & Reduce cost of occupancy pool. & $2 / 5 / 98$ & $2 / 5 / 98$ & & & & \\
\hline 84 & UTILITIES TRAINING & $2 / 5 / 98$ & $2 / 5 / 98$ & & & & \\
\hline 85 & $\begin{array}{l}\text { Reduce in-house training organization and utilize PHMC training organization and outside } \\
\text { contractors for specific needs. }\end{array}$ & $2 / 5 / 98$ & $2 / 5 / 98$ & (A) & & & \\
\hline 86 & SITE CRANE \& RIGGING SERITCES & $2 / 5 / 98$ & $2 / 5 / 98$ & & & & \\
\hline 87 & Align workforce with changing requirements in the $1100 / 300 / 100$ Areas. & $2 / 5 / 98$ & $2 / 5 / 98$ & & & & \\
\hline 88 & SITE FABRICATION SERVICES & 10/1/97 & $2 / 5 / 98$ & & & & \\
\hline 89 & $\begin{array}{l}\text { Eliminate associated with reduced work scope and direct charging indirect activities. } \\
\text { Eliminate position and spread responsibilities to other managers. }\end{array}$ & $10 / 1 / 97$ & $2 / 5 / 98$ & & & & \\
\hline 90 & WATER OPERATIONS & $10 / 1 / 97$ & $10 / 30 / 01$ & & & & \\
\hline 91 & Replace pumps and motors in 300 Area, oversized for current requirements. & $12 / 19 / 97$ & $4 / 1 / 98$ & & & & \\
\hline 92 & Replace pumps and motors in 300 Area oversized for current requirements. & $1 / 1 / 99$ & $9 / 30 / 99$ & & & & \\
\hline 93 & Replace Building 312 River Pumps & $1 / 1 / 99$ & $6 / 30 / 99$ & & & & \\
\hline 94 & Replace Building 315 Export Pumps & $3 / 30 / 99$ & $9 / 30 / 99$ & & & & \\
\hline 95 & $\begin{array}{l}\text { Improve efficiencies in water purification operations by attomating operations and by closing } \\
200 \text { East filter plant. (Project } L-286 \text { ) }\end{array}$ & $10 / 1 / 97$ & 6/30/99 & & & & \\
\hline 96 & $\begin{array}{l}\text { Streamline operations that provide water supply to } 100,200 \mathrm{E} \text {, and } 200 \mathrm{~W} \text { Areas through } \\
\text { consolidation and technology upgrades }\end{array}$ & $10 / 1 / 99$ & $10 / 30 / 01$ & & & & \\
\hline 97 & ELECTRICAL UTILITIES & $3 / 2 / 98$ & $9 / 30 / 98$ & & & & \\
\hline
\end{tabular}

Portions of this page may have blankes or missing information due to the information being Company Sensitive and/or Business Proprietary

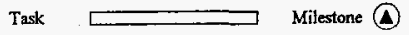

Progress

Summary 


\section{F-1. MULTI-YEAR SCHEDULE}

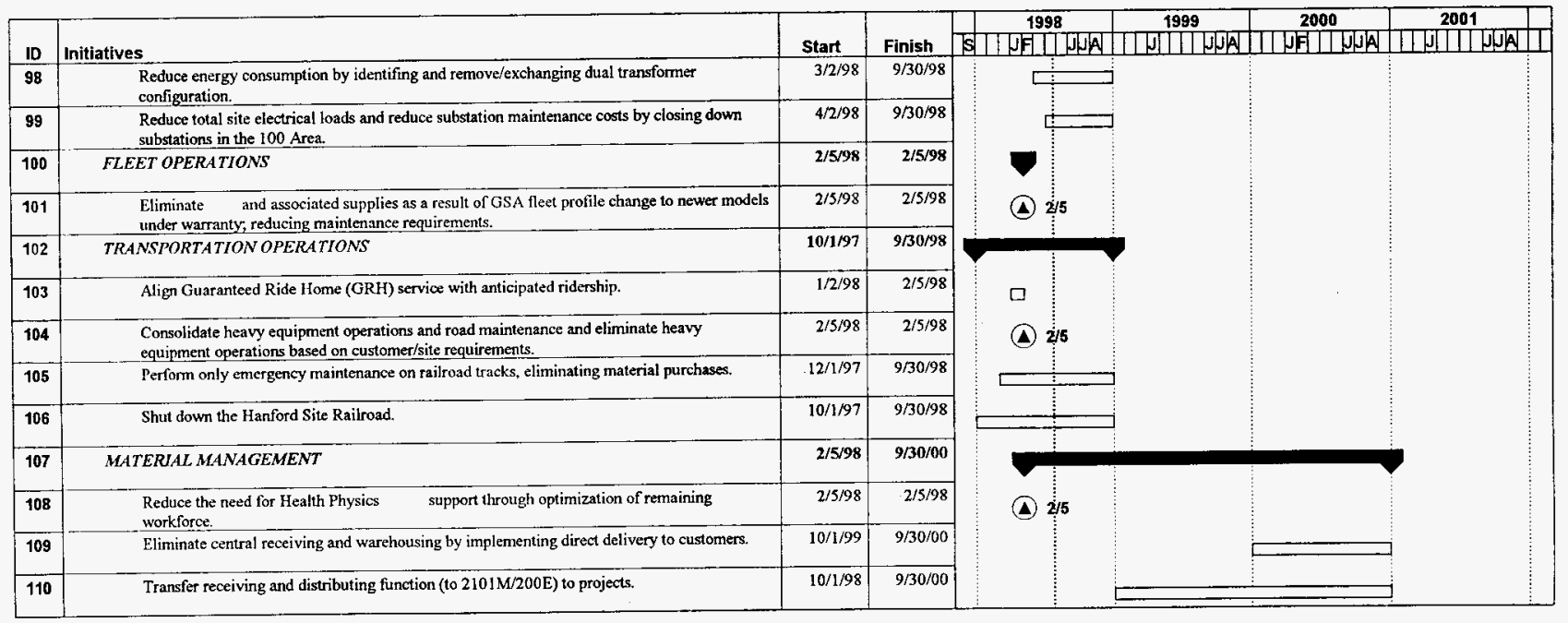

Portions of this page may have blankes or missing information due to the information being Company Sensitive and/or Business Proprietary

Scheduler: Clinton D. (Clint) Donley
Task

Progress

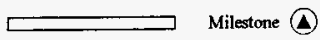

Summary 


\section{Strategic Plan for \\ Infrastructure Optimization}

G - ORGANIZATIONAL CHANGES 


\section{Strategic Plan for \\ Infrastructure Optimization}

\section{G-1. ORGANIZATIONAL CHANGES}




\section{DYNCORP TRI-CITIES SERVICES, INC.}




\section{DYNCORP TRI-CITIES SERVICES, INC.}




\section{DYNCORP TRI-CITIES SERVICES, INC.}

Proposed Organization Structure As of October 1, 1998 


\section{FACILITIES MAINTENANCE \& SITE SERVICES}




\section{ENGINEERING}

(Formerly Facilities Maintenance and Site Services)

Organization Structure As of February 5, 1998

Portions of this page may have blanks or missing information due to 
望

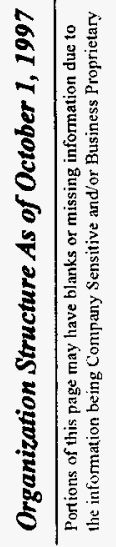


登

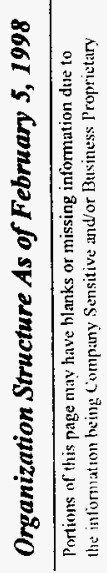


量

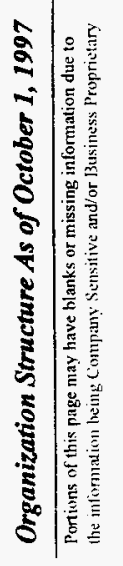




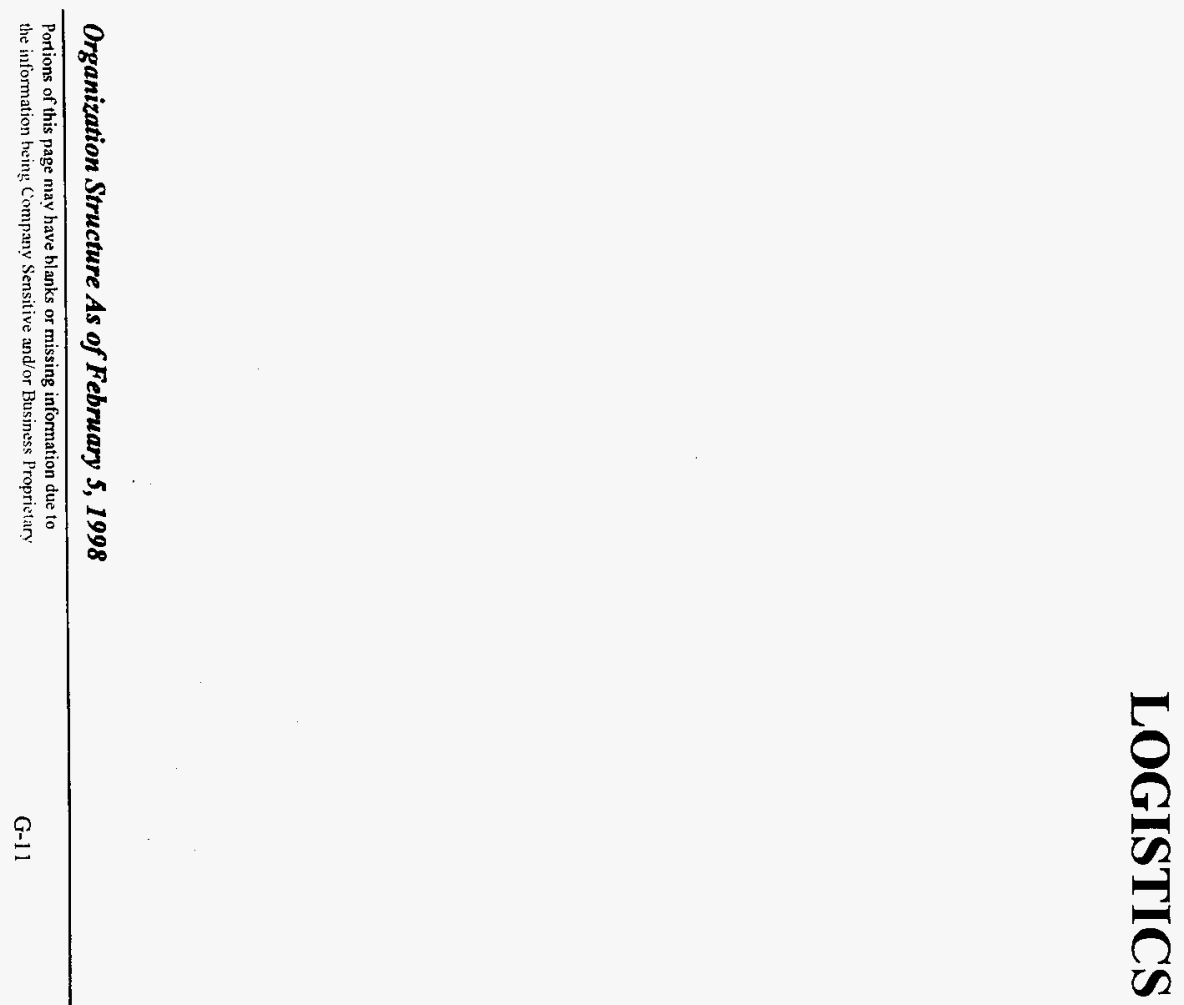




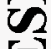

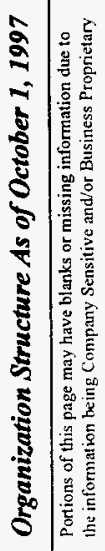


$\frac{1}{23}$

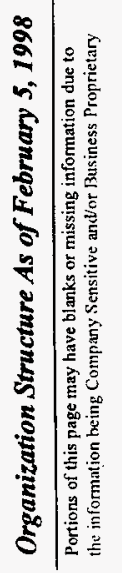




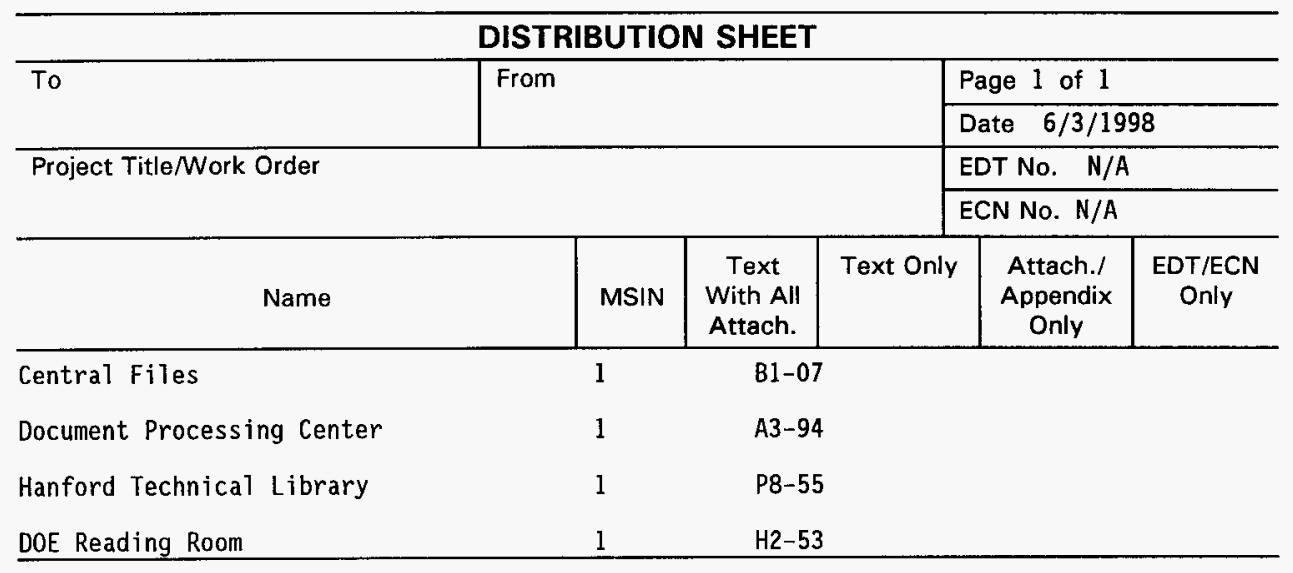

